\title{
Rare earth elements of sediments in rivers and estuaries of the east coast of India
}

\author{
Shaik Sai Babu ${ }^{1}$, R. Venkata Ramana ${ }^{1}$, V. Purnachandra Rao ${ }^{1, *}$, \\ M. Ram Mohan ${ }^{2}$, S. Sawant ${ }^{2}$, N. Satyasree ${ }^{1}$ and A. Keshav Krishna ${ }^{2}$ \\ ${ }^{1}$ Vignan's Foundation for Science, Technology and Research, Deemed to be Vignan's Univesity, Vadlamudi 522 213, India \\ ${ }^{2}$ CSIR-National Geophysical Research Institute, Uppal Road, Hyderabad 500 007, India
}

\begin{abstract}
The rare earth elements (REE) in the clay fraction of sediments in 15 rivers and their estuaries along the east coast of India were analysed in this study. The total REE content ( $\sum$ REE) varied from 130.98 to $289.85 \mu \mathrm{g} / \mathrm{g}$ and from 70.89 to $352.61 \mu \mathrm{g} / \mathrm{g}$ in rivers and estuaries respectively. The $\Sigma$ REEs of estuarine clays (except the Brahmani and Baitarani) was lower than in rivers. The Post-Archean average Australian Shale-normalized REE patterns in rivers and estuaries were similar and categorized into three types. The REE patterns reflect the composition of dominant geological formations in river basins and extent of sediment mixing from different sources during transport. Hydrodynamic conditions controlled the abundance and fractionation of REE in the estuaries. The $\mathrm{Sm} / \mathrm{Nd}$ ratios of clays were largely controlled by mineral composition and $\mathrm{Y} / \mathrm{Ho}$ ratios were affected by sedimentary processes in the estuaries.
\end{abstract}

Keywords: Estuaries, rare earth elements, rivers, sediments, volcanic rocks.

RARE earth elements (REE), because of their unique and chemically coherent behaviour, are commonly used as geochemical tracers for provenance studies ${ }^{1,2}$. The distribution of REE in natural waters, suspended particulate matter and sediments in rivers and estuaries has been extensively studied ${ }^{2-10}$. Significant progress has been achieved in our understanding of REE distribution in the sediments. For example, earlier studies had indicated that 'REE as a group are insoluble elements, exhibit little fractionation during the Earth surface processes" ${ }^{1}$. This was refuted in the subsequent studies and it was suggested that the REE are fractionated and mobilized during weathering in all types of climatic conditions and in estu$\operatorname{aries}^{5,6,11-16}$. Moreover, Fe-Mn oxyhydroxides, colloidal material and organic compounds could also be hosts for REE and their presence in sediments could bias total REE concentration $^{17-20}$. The type of weathering ${ }^{21}$, lithology of the rocks and their susceptibility to erosion ${ }^{22}$ also control the degree of REE fractionation in the silt and clay fractions of sediments. Fractionation within REE groups, i.e.

*For correspondence. (e-mail: vprao55@gmail.com) among light-REE (LREE), middle-REE (MREE) and heavy-REE (HREE) has been reported in different size fractions of sediments ${ }^{18,23}$, and attributed to the presence and amount of heavy minerals and carbonate fraction in the sediments $8,9,24,25$. In other words, several factors contribute to the mobilization, fractionation and concentration of REE in sediments and therefore place a limit on the use of REE geochemistry for provenance studies.

Several studies have focused on REE distribution in the sediments of large rivers, because they cover extensively large areas and help better understand the global REE cycle $^{26}$. However, it is difficult to identify the sourcerock characteristics from sediments of large rivers, because they drain through different rock types under varied climatic conditions, and REE from different sources are admixed during weathering, erosion, transportation and deposition, resulting in homogenous REE patterns in large rivers of the world ${ }^{18}$. REE were abundantly removed to the sediments in several estuaries ${ }^{6}$, but low REE removal in low-salinity regions $(<5)$ has also been reported $^{10}$. In our earlier study, the composition of peninsular India rivers average clay (PIRAC) ${ }^{27}$ was compared with that of world river average clay (WRAC) and other reference crustal sediments from different continents. In the present study, sediments collected in the lower reaches of 15 rivers, low-salinity regions $(<5)$ of their estuaries and two lakes along the east coast of India were analysed in detail for REE geochemistry (Figure 1). The purpose of the study was to: (a) report REE distribution in clay fraction of sediments in rivers and document that this fraction represents dominant source-rock characteristics in their drainage basins, and (b) verify whether the estuarine sediments enriched in REE, similar to that reported in the literature.

\section{Materials and methods}

\section{Study area and samples}

Several rivers draining peninsular and extra-peninsular India bring suspended and bed-load of sediments to the Bay of Bengal. Figure 1 shows the generalized geological map of India $^{28}$, and location of the rivers and lakes 


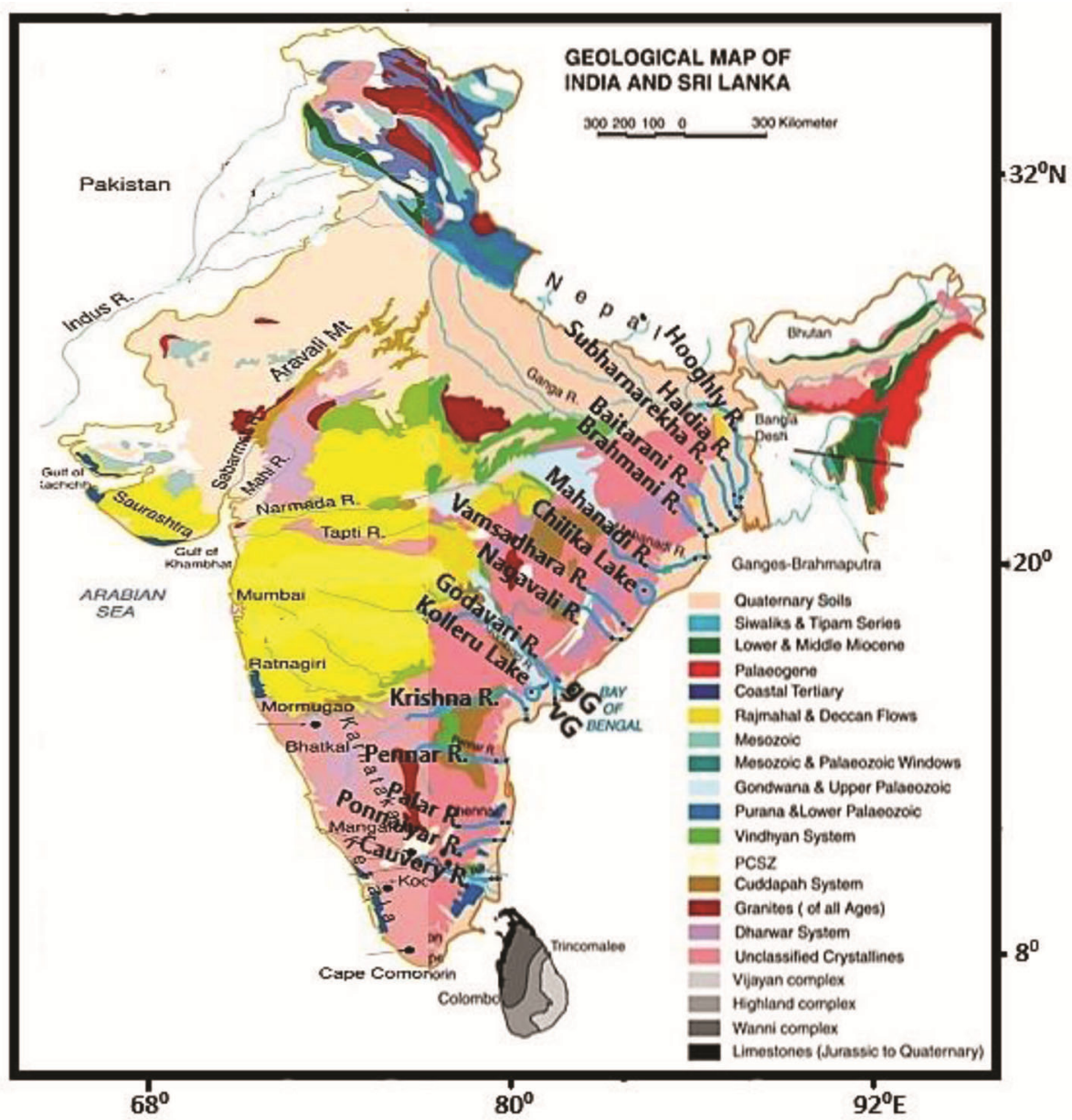

Figure 1. Generalized geological map of India ${ }^{28}$. Rivers and lakes along the east coast of India analysed for their sediments in this study are also shown.

analysed in this study. Table 1 provides details of the major and medium rivers ${ }^{29}$ (length, drainage basin area and annual discharge) and geological formations in their drainage basins. The predominant rock formations are the Archean and Pre-Cambrian ${ }^{30,31}$ in the drainage basins of the Cauvery, Ponnaiyar, Palar and Pennar rivers, the Deccan Trap volcanic rocks ${ }^{32,33}$ in the Krishna and Godavari rivers, the Eastern Ghats gneissic rocks ${ }^{34,35}$ (khondalites) consisting of Mn ore deposits for the Nagavali and Vamsadhara rivers, and both igneous and metamorphic rocks and different soils (mixed lithology terrain) (36-38 $^{\text {in the }}$ Mahanadi, Brahmani, Baitarani, Subarnarekha, Haldia and Hoogly rivers (Table 1). The sediments in the lower reaches of rivers are usually derived from different geological formations in their drainage basins, and admixed thoroughly during transportation and deposition. In order to meet the objectives of the study, two sediments, one in the lower reaches of 15 rivers and another in the lowsalinity region $(<5)$ of their estuaries and two lakes (one freshwater lake and one brackish-water lake) along the east coast of India were collected, using Peterson grab and with the help of a mechanized boat. A total of 32 sediment samples were collected and dried in an oven at $<60^{\circ} \mathrm{C}$.

\section{Analytical methods}

The sand, silt and clay contents of 32 sediments were determined following Folk ${ }^{39}$. The geochemistry of the clay fraction $(<4 \mu \mathrm{m})$ of sediments was used to understand the provenance. The $<62 \mu \mathrm{m}$ fraction of the sediments were separated from the total sediments by wet sieving using 230 (ASTM) mesh sieve. This fraction was collected in a measuring glass cylinder, made up to $1000 \mathrm{ml}$ volume with distilled water and stirred vigorously for homogeneity. The $<4 \mu \mathrm{m}$ fraction of the sediments was separated based on the Stoke's settling velocity ${ }^{39}$, dried in oven at $60^{\circ} \mathrm{C}$ and then powdered. One gram of dried sample powder was used to prepare pellets. Major elements were determined using an X-ray fluorescence spectrometer 'WD-XRF' (model Axios mAX, PANAnalytical), at the CSIR-National Geophysical Research Institute (CSIR-NGRI), Hyderabad. For trace elements, 


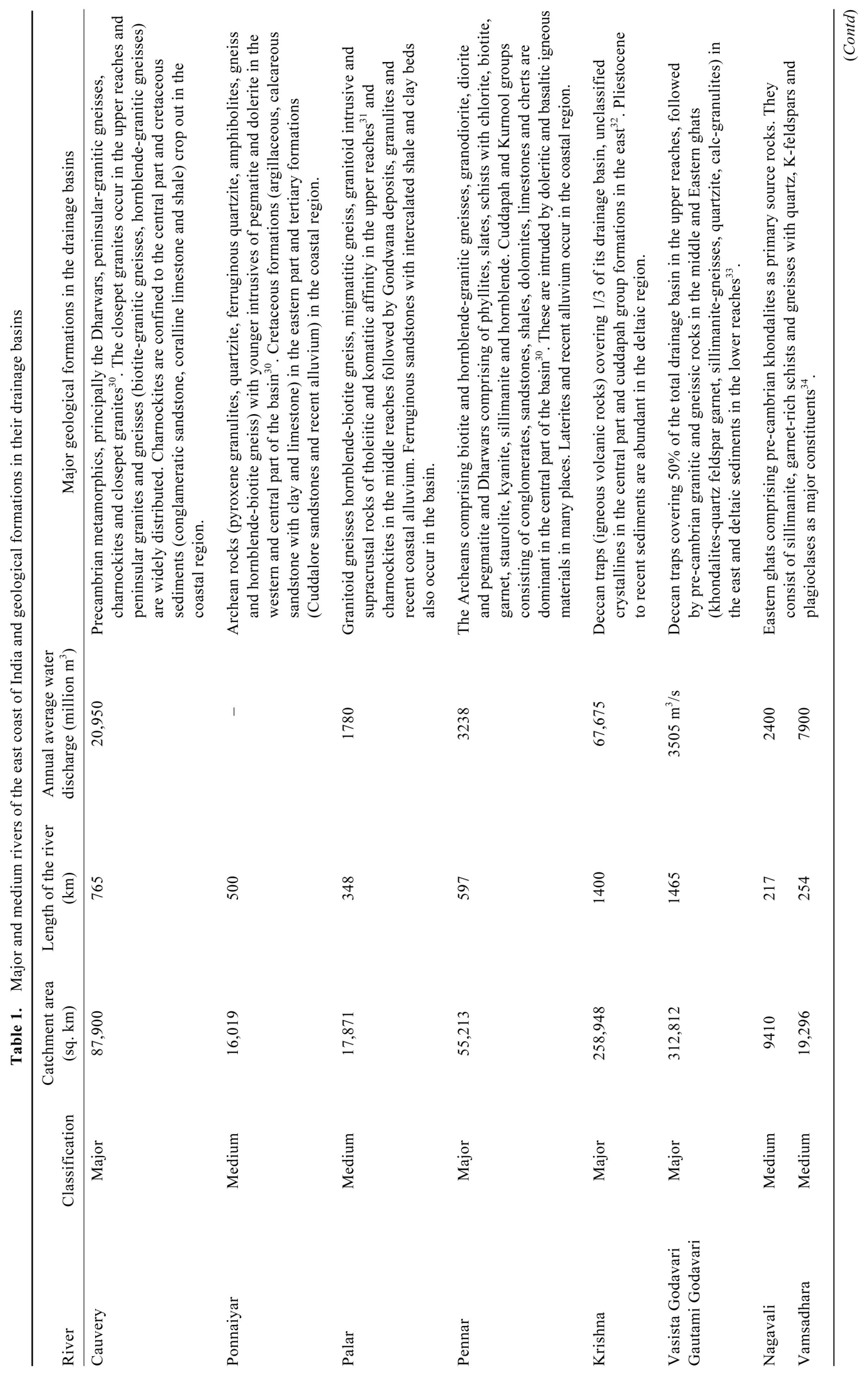




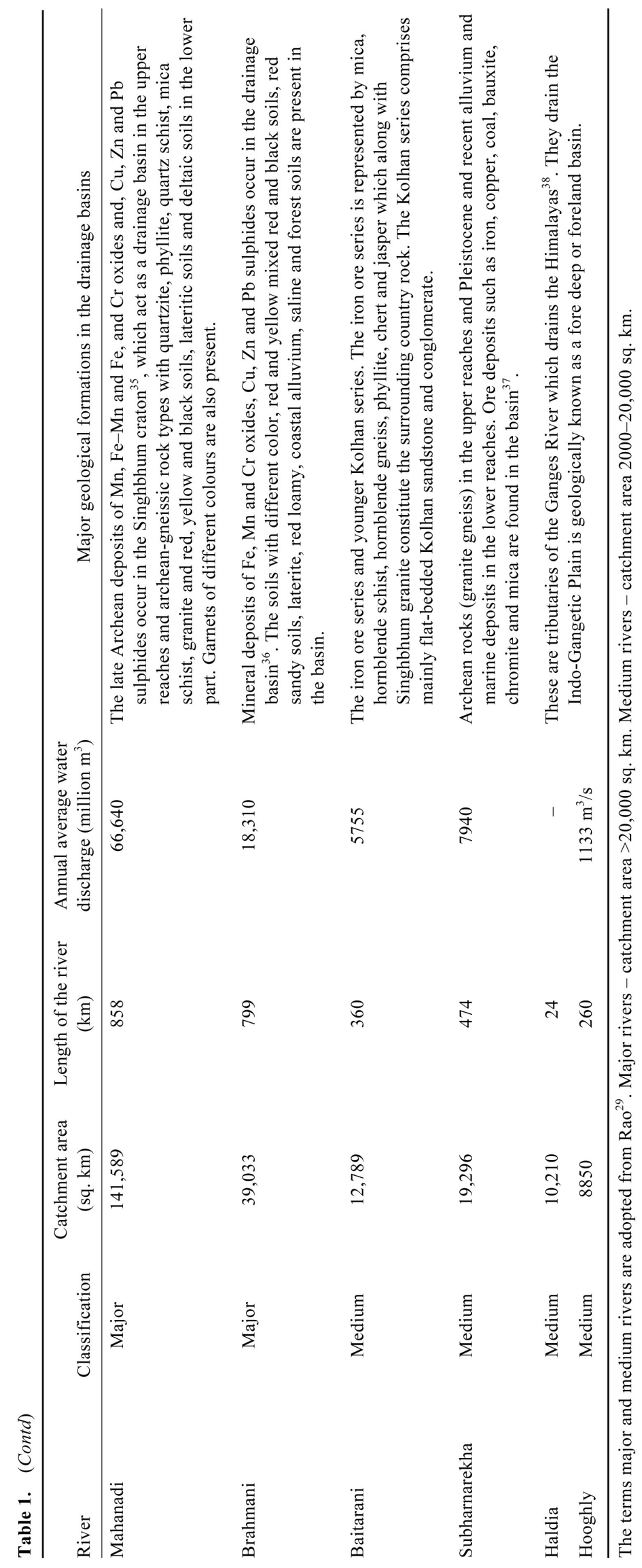


Table 2. Comparative rare earth elements (REE) data of certified reference materials (MAG-1 and $\mathrm{Jsd}-1 ; \mu \mathrm{g} / \mathrm{g}$ ) against the data obtained by HR-ICP-MS in the present study

\begin{tabular}{|c|c|c|c|c|c|c|c|c|c|}
\hline \multirow[b]{2}{*}{ Analyte } & \multirow[b]{2}{*}{ Mass no. } & \multicolumn{4}{|c|}{ MAG-1 (calibrating standard) } & \multicolumn{4}{|c|}{ Jsd-1 (cross-check standard) } \\
\hline & & $\mathrm{A}$ & B & $\mathrm{SD}$ & $\%$ RSD & AA & $\mathrm{BB}$ & SD & $\%$ RSD \\
\hline $\mathrm{La}$ & 139.00 & 43.00 & 44.66 & 0.98 & 2.19 & 18.60 & 19.78 & 0.73 & 3.67 \\
\hline $\mathrm{Ce}$ & 140.00 & 88.00 & 91.59 & 1.90 & 2.08 & 35.40 & 39.47 & 1.37 & 3.48 \\
\hline $\operatorname{Pr}$ & 141.00 & 9.30 & 9.76 & 0.22 & 2.28 & 4.00 & 4.36 & 0.14 & 3.32 \\
\hline $\mathrm{Nd}$ & 146.00 & 38.00 & 39.39 & 0.99 & 2.51 & 17.80 & 18.93 & 0.68 & 3.58 \\
\hline $\mathrm{Sm}$ & 147.00 & 7.50 & 7.68 & 0.11 & 1.47 & 3.87 & 4.00 & 0.11 & 2.65 \\
\hline $\mathrm{Eu}$ & 153.00 & 1.55 & 1.62 & 0.04 & 2.59 & 0.92 & 1.17 & 0.04 & 3.16 \\
\hline Gd & 157.00 & 5.80 & 6.23 & 0.18 & 2.82 & 2.60 & 3.41 & 0.15 & 4.36 \\
\hline $\mathrm{Tb}$ & 159.00 & 0.96 & 1.01 & 0.03 & 2.67 & 0.40 & 0.55 & 0.02 & 4.16 \\
\hline Dy & 163.00 & 5.20 & 5.42 & 0.14 & 2.61 & 2.10 & 2.96 & 0.12 & 4.11 \\
\hline$Y$ & 89.00 & 28.00 & 28.74 & 0.81 & 2.82 & 15.70 & 16.75 & 0.48 & 2.85 \\
\hline Ho & 165.00 & 1.02 & 1.06 & 0.04 & 3.47 & 0.30 & 0.57 & 0.03 & 5.36 \\
\hline $\mathrm{Er}$ & 166.00 & 3.00 & 3.10 & 0.09 & 2.94 & 0.60 & 1.67 & 0.06 & 3.60 \\
\hline $\mathrm{Tm}$ & 169.00 & 0.43 & 0.44 & 0.01 & 2.03 & 0.19 & 0.23 & 0.01 & 4.07 \\
\hline $\mathrm{Yb}$ & 172.00 & 2.60 & 2.67 & 0.08 & 2.96 & 1.39 & 1.37 & 0.05 & 3.94 \\
\hline $\mathrm{Lu}$ & 175.00 & 0.40 & 0.41 & 0.01 & 1.83 & 0.20 & 0.21 & 0.01 & 3.56 \\
\hline
\end{tabular}

A, Certified values of MAG-1, B, Results obtained from HR-ICP-MS analysis for MAG-1 (average of four analyses), AA, Certified values of Jsd-1, BB, Results obtained from HR-ICP-MS analysis for Jsd-1 (average of four analyses). Reported values are from Govindaraju ${ }^{41}$; GEOREM (georem.mpchmainz.gwdg.de).

$50 \mathrm{mg}$ of the homogenized powdered sediment sample was transferred into Teflon beaker and $10 \mathrm{ml}$ of acid mixture $\left(7: 3\right.$ of $\mathrm{HF}$ and $\mathrm{HNO}_{3}$ ) was added to each beaker, kept overnight on a hot plate at $150^{\circ} \mathrm{C}$ for $48 \mathrm{~h}$. Two drops of $\mathrm{HClO}_{4}$ were added to the beaker and evaporated at $150^{\circ} \mathrm{C}$ for $\sim 1 \mathrm{~h}$ to near dryness. This procedure was repeated till the sample in the beaker was completely digested. The final residue was dissolved in $10 \mathrm{ml}$ of $1: 1$ water and $\mathrm{HNO}_{3}$ mixture. Next, $5 \mathrm{ml}$ of $1 \mathrm{ppm} \mathrm{Rh}{ }^{103}$ solution was added to the beaker as an internal standard and final volume of the sample solution was made up to $250 \mathrm{ml}$. High-resolution inductively coupled plasma mass spectrometer (HR-ICP-MS; $\mathrm{Nu}$ Instruments, UK) at CSIR-NGRI, was used for analysis of the sample solutions. MAG-1 (marine mud), certified reference material (CRM) from the United States Geological Survey was used as calibrating standard for the analysis of sediments and, JSd-1, CRM for stream sediments from the Geological Survey of Japan was used as a cross-check standard for the data. $\mathrm{Rh}^{103}$ was used as an internal standard for instrument drift correction. Details of instrument parameters and HR-ICP-MS analysis with accuracy and precision achieved are given in Satyanarayanan et al. ${ }^{40}$. Table 2 shows relative standard deviation (RSD) for MAG-1 standard and reported values ${ }^{41}$ using HR-ICP-MS.

The chemical index of alteration (CIA) of sediments was calculated, following the equation ${ }^{42}$ given in Table 3 . The REE were subdivided into LREE (La-Nd), MREE (Sm-Ho) and HREE (Er-Lu), following Rollinson ${ }^{2}$. The $\mathrm{Ce}\left(\mathrm{Ce} / \mathrm{Ce}^{*}\right)$ and $\mathrm{Eu}\left(\mathrm{Eu} / \mathrm{Eu}^{*}\right)$ anomalies were calculated (Table 3$)^{43}$. Carbonate content of the sediments was calculated based on weight loss method, by weighing the sediment sample before and after dissolving carbonate in the sample with $10 \% \mathrm{HCl}$, followed by washing for acid removal and drying. The difference in weight was considered as the carbonate content and percentage was calculated. This procedure was repeated three times for each sample and carbonate content $(\%)$ of the sample was the mean of three values.

\section{Results}

\section{$\Sigma R E E$ and its relation with light elements and heavy metals}

Tables 3 and 4 show the major elements, rare earth elements (REE) and trace metals in the clay $(<4 \mu \mathrm{m})$ fraction of sediments. The total REE content ( $\left.\sum \mathrm{REE}\right)$ of the clays varied from 130.98 to $289.85 \mu \mathrm{g} / \mathrm{g}$ (Figure 2; Table 3 ) in 15 rivers and a freshwater (Kolleru) lake. The average $\sum$ REE of the rivers and lake was slightly lower than that of the WRAC ${ }^{18}(205.14 \mu \mathrm{g} / \mathrm{g})$ and Post-Archean average Australian Shale ${ }^{44}$ (PAAS: $208.67 \mu \mathrm{g} / \mathrm{g}$ ). The $\sum$ REE was higher $(230-290 \mu \mathrm{g} / \mathrm{g})$ than in PAAS in some major (Gautami Godavari, Mahanadi and Brahmani) and medium (Nagavali and Baitarani) rivers (Figure 2).

Similarly, $\sum$ REE was lower $(130-144 \mu \mathrm{g} / \mathrm{g})$ than in the upper continental crust $^{45}$ (UCC: $148.97 \mu \mathrm{g} / \mathrm{g}$ ) in both medium (Palar) and major (Krishna) rivers. The $\sum$ REE of the estuarine clay $(70.89-352.61 \mu \mathrm{g} / \mathrm{g})$ was lower than that of the corresponding river, except in the Brahmani and Baitarani estuaries (Figure 2 and Table 4).

Scatter plots showed that $\sum$ REE was positively correlated with clay content, both in rivers and estuaries (Figure $3 a$ ). The correlation of $\sum$ REE with $\mathrm{Al}_{2} \mathrm{O}_{3}$ 


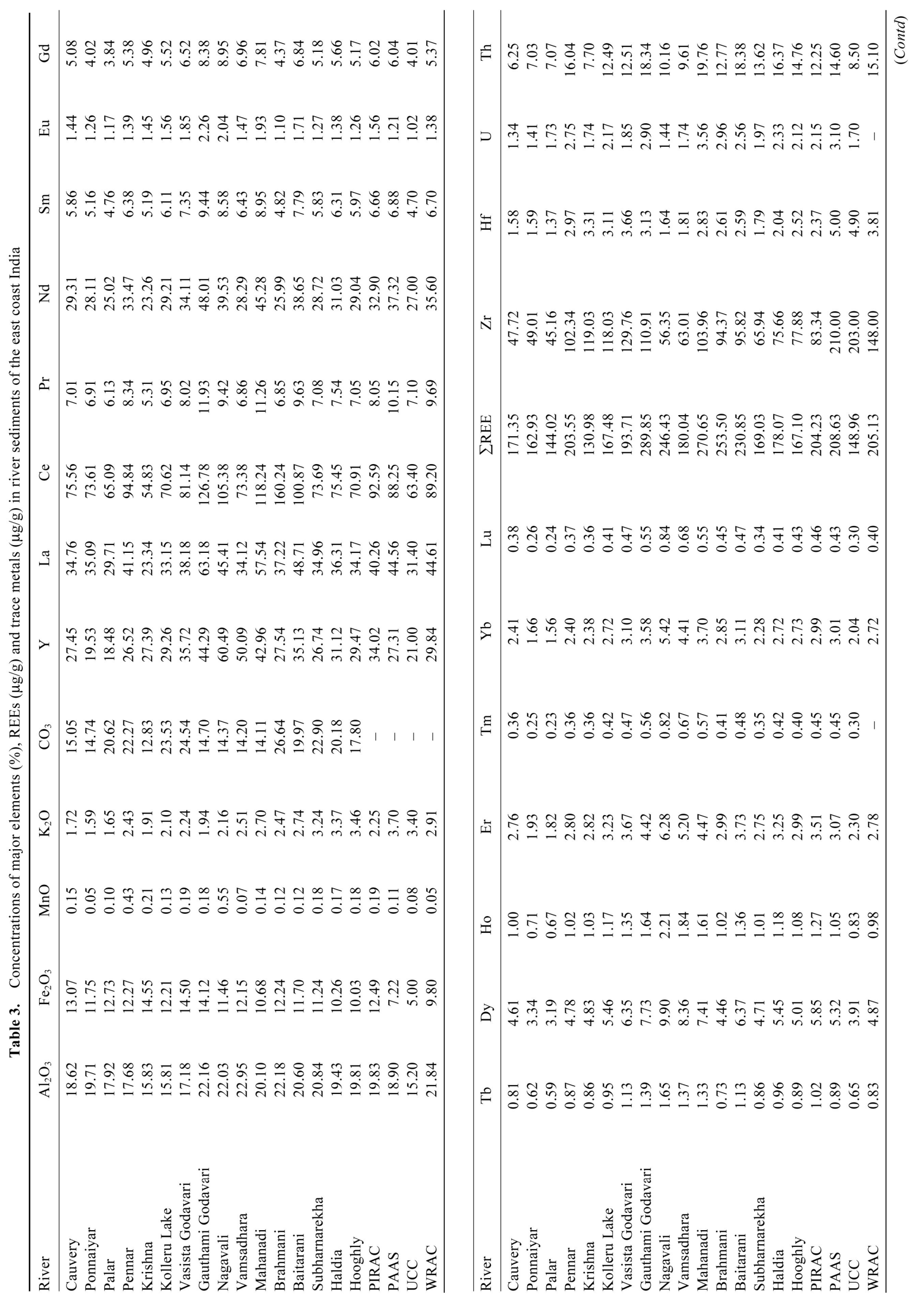




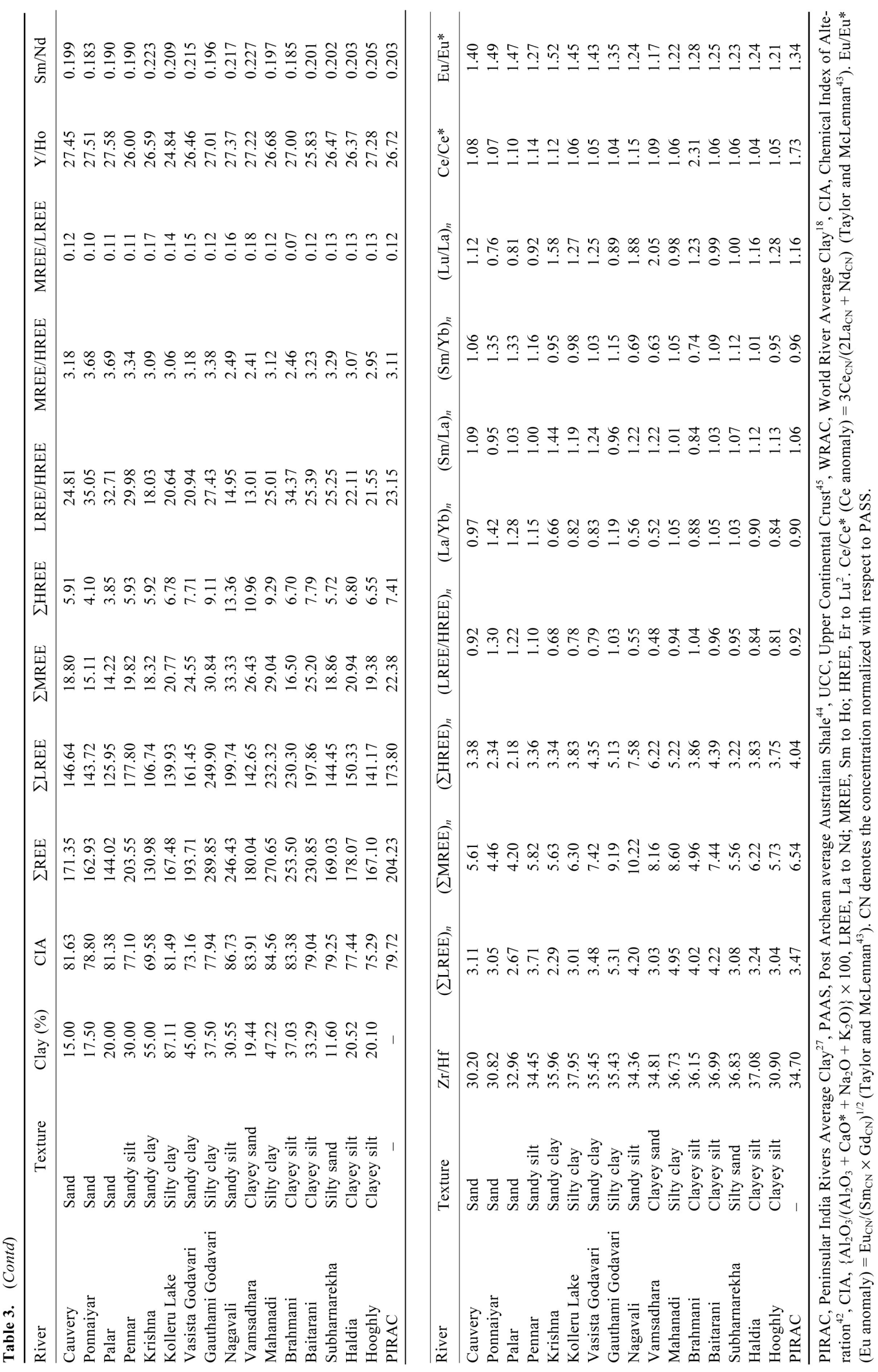




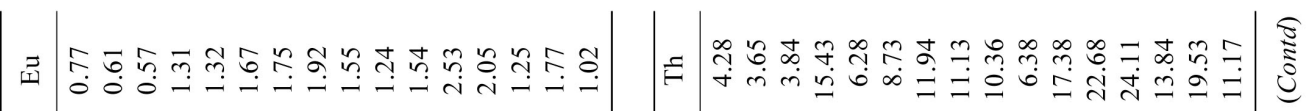

责

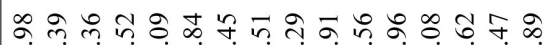

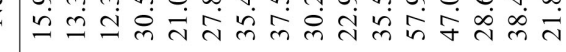

\#

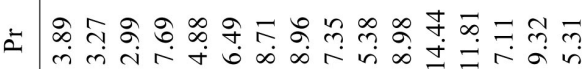

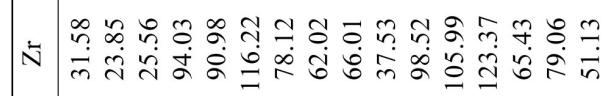

- 苯舟

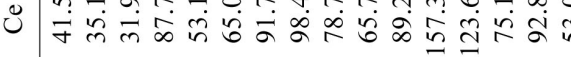

অ

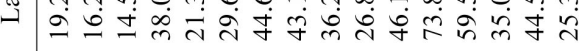

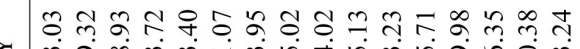

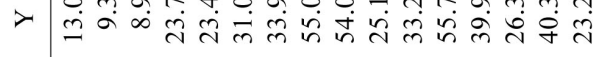

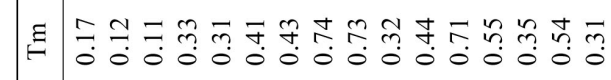



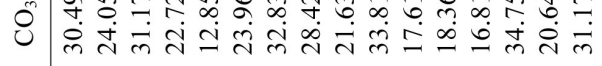

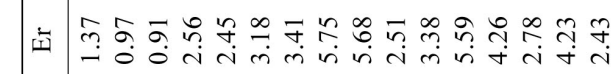

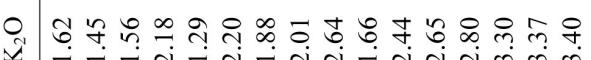

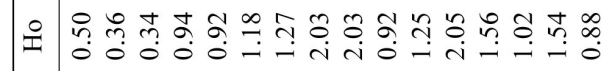

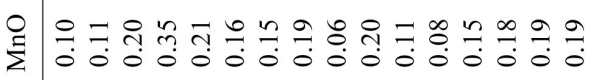

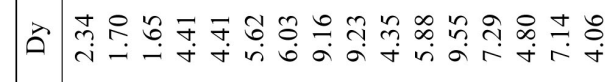

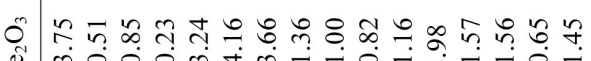

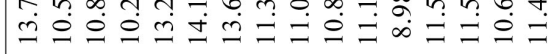

을

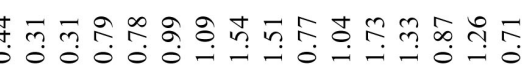

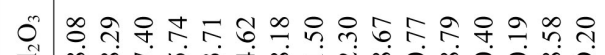

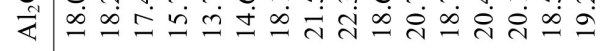

J

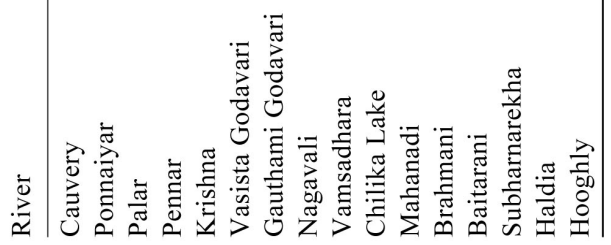

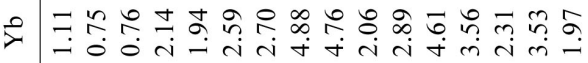




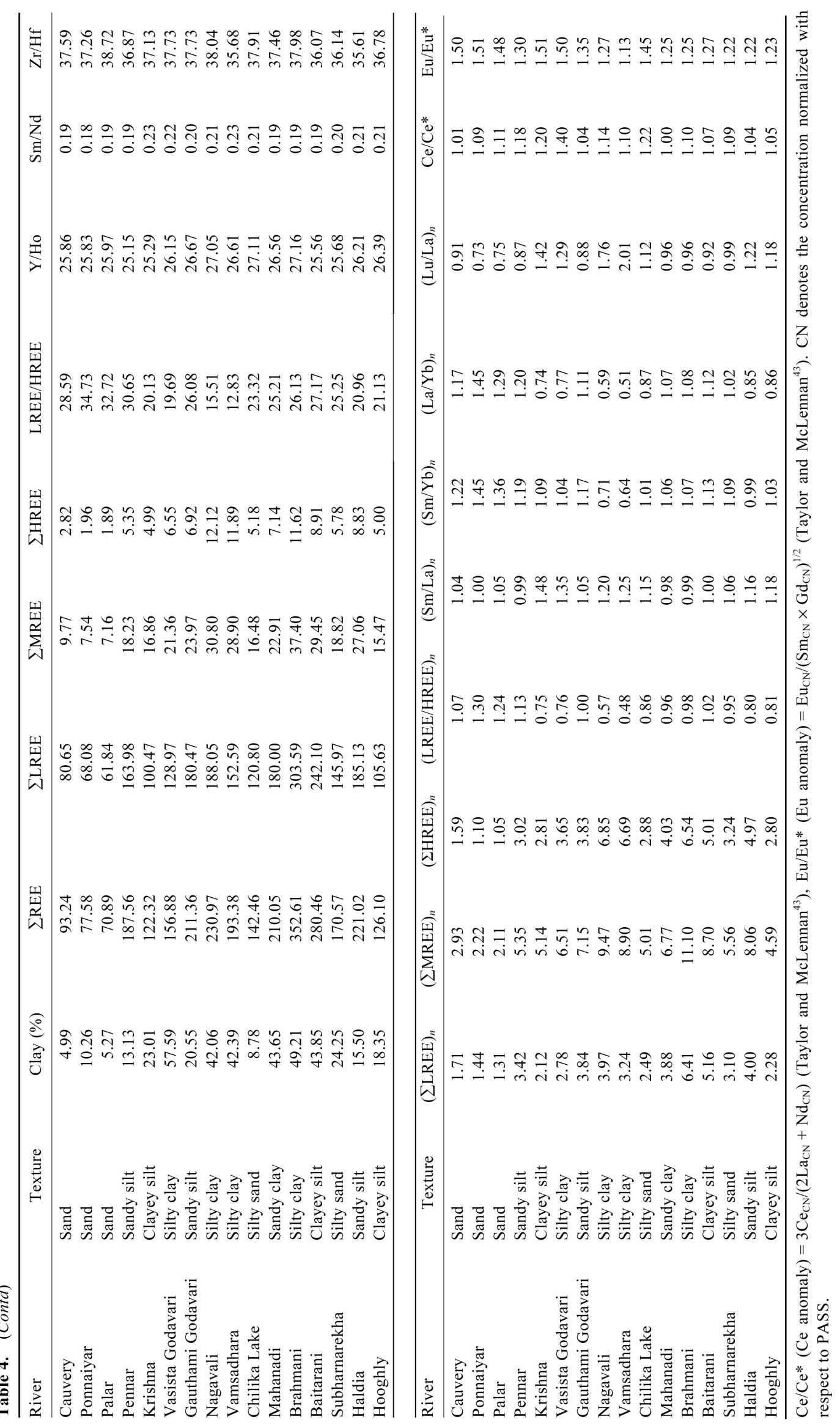


$(r=0.7)$ and $\mathrm{K}_{2} \mathrm{O}(r=0.75$; Figures $3 b$ and $d)$ was strong and statistically significant $(P>0.001)$ in river clay. $\sum$ REE was moderately correlated with $\mathrm{Fe}_{2} \mathrm{O}_{3}(r=0.64$; $P<0.05$; Figure $3 d$ ). In estuarine clay, $\sum$ REE showed moderate correlation with $\mathrm{Al}_{2} \mathrm{O}_{3}(r=0.52 ; P>0.05)$ and weak correlation with $\mathrm{Fe}_{2} \mathrm{O}_{3}(r=0.48 ; P>0.1$; Figure $3 b-d)$. The correlation of $\sum \mathrm{REE}$ with $\mathrm{K}_{2} \mathrm{O}(r=0.81)$ was strong and statistically most significant $(P<0.001)$. The correlations between $\sum \mathrm{REE}$ and heavy metals $(\mathrm{Zr}, \mathrm{Hf}, \mathrm{U}$, Th) were positive and statistically significant $(P>0.001)$ in river clays and statistically most significant $(P<0.001)$ in estuarine clay (Figure $4 a-d$ ). The carbonate content was lower in rivers than in estuaries (Tables 3 and 4). $\sum$ REE was moderately correlated $(r=0.58)$ with carbonate content in river clay, but weak and negatively correlated $(r=-0.51)$ in estuarine clay.

The inter-relationship among REE revealed that $\Sigma$ LREE was moderately correlated with $\sum$ MREE and $\sum$ HREE $(r=0.45-0.59 ; P>0.5$ to 0.001 ; Figure $5 a$ and $b)$, but $\sum$ MREE showed strong correlation with $\sum$ HREE $(r=0.92 ; P<0.001)$ in river sediments (Figure $5 c$ ). Linear and positive correlations existed among $\sum$ LREE, $\sum$ MREE and $\sum$ HREE in estuarine clay (Figure $5 a-c$ ). $(\mathrm{La} / \mathrm{Yb})_{n}$ was significantly correlated with the $\sum$ LREE/ $\sum$ HREE ratio in river and estuarine clay and reference sediments (Figure $5 d$ ).

\section{$\mathrm{Sm} / \mathrm{Nd}$ and $\mathrm{Y} / \mathrm{Ho}$ ratios}

Scatter plots showed linear correlation of Sm with $\mathrm{Nd}$, and $\mathrm{Y}$ with Ho (Figure $6 a$ and $c$ ). The $\mathrm{Sm} / \mathrm{Nd}$ ratio in river clay was marginally lower than in estuaries (Figure $6 b$ ). The average $\mathrm{Sm} / \mathrm{Nd}$ ratio was same for the rivers dominantly draining the Archean and Pre-Cambrian crust (0.201) and mixed lithology crust (0.199), but slightly high $(0.211)$ for rivers draining the volcanic crust. The Y/Ho ratio of clay ranged from 26.0 to 27.5 and from 25.1 to 27.1 in rivers and estuaries respectively (Figure $6 d$ ). The average Y/Ho ratio for rivers dominantly draining the volcanic crust (26.2) was lower than that of Archean and Pre-Cambrian crust (27.2) and mixed lithology crust (26.6).

\section{PAAS-normalized REE patterns, Ce and Eu anomalies}

The PAAS-normalized REE patterns of river clay, except the Brahmani, showed MREE enrichment $\left((\mathrm{Sm} / \mathrm{La})_{n}\right.$ and $(\mathrm{Sm} / \mathrm{Yb})_{n}$ ratios varied from 0.95 to 1.24 and from 0.95 to 1.35 respectively; Table 3 ) over LREE and HREE (Figure 7). They can be categorized into three types, based on the predominant geological formations in the drainage basins of rivers (Figure 1 and Table 1). Type-1 REE patterns varied widely among six rivers which drain predominantly the Archean and Pre-Cambrian gneissic formations. For example, the Ponnaiyar and Palar river clay showed LREE (av $\left.(\mathrm{La} / \mathrm{Yb})_{n}=1.35\right)$ and MREE-enriched and HREE-depleted $\left(\right.$ av $(\mathrm{Lu} / \mathrm{La})_{n}$ ratio $\left.=0.78\right)$ REE patterns, whereas the Cauvery and Pennar river clays showed MREE enrichment and near equal proportions of LREE $\left(\mathrm{av}(\mathrm{La} / \mathrm{Yb})_{n}\right.$ ratio $\left.=1.06\right)$ and HREE $\left(\mathrm{av} \quad(\mathrm{Lu} / \mathrm{La})_{n}\right.$ ratio $=1.02)$. The Nagavali and Vamsadhara river clays showed LREE-depleted $\left(\mathrm{av}(\mathrm{La} / \mathrm{Yb})_{n}\right.$ ratio $\left.=0.54\right)$ and MREE- and HREE-enriched $\left(\mathrm{av}(\mathrm{Lu} / \mathrm{La})_{n}\right.$ ratio $\left.=1.96\right)$ patterns. Clays from the Krishna and Godavari rivers and Kolleru Lake showed type-2 REE patterns, characterized by LREE-depletion $\left(\mathrm{av} \quad(\mathrm{La} / \mathrm{Yb})_{n} \quad\right.$ ratio $\left.=0.87\right)$ and MREE- and HREE-enrichment (av $(\mathrm{Lu} / \mathrm{La})_{n}$ ratio $\left.=1.24\right)$. These rivers drain predominantly the Deccan Traps. The type-3 REE patterns were MREE-enriched with near equal proportions of LREE (av $\left.(\mathrm{La} / \mathrm{Yb})_{n}=0.95\right)$ and HREE (av $\left.(\mathrm{Lu} / \mathrm{La})_{n}=0.94\right)$. Clays from the Mahanadi, Brahmani, Baitarini, Subarnarekha, Haldia and Hoogly rivers showed type-3 patterns. These rivers drain predominantly mixed lithology (Table 1). The REE patterns in the estuarine clays were nearly identical to that of rivers. Positive $\mathrm{Ce}$ and $\mathrm{Eu}$ anomalies were present both in river and estuarine clays (Figure 7). Clays from the Chilika Lake, a brackish-water lake, showed type-3 REE patterns (Figure 7).

The Ce anomaly $\left(\mathrm{Ce} / \mathrm{Ce}^{*}\right)$ values (Figure $8 a$ ) were in the narrow range (1.04 to 1.15) for river clays, except Brahmani (2.31). The average $\mathrm{Ce} / \mathrm{Ce}^{*}$ value was not different for rivers draining the dominant Archean and

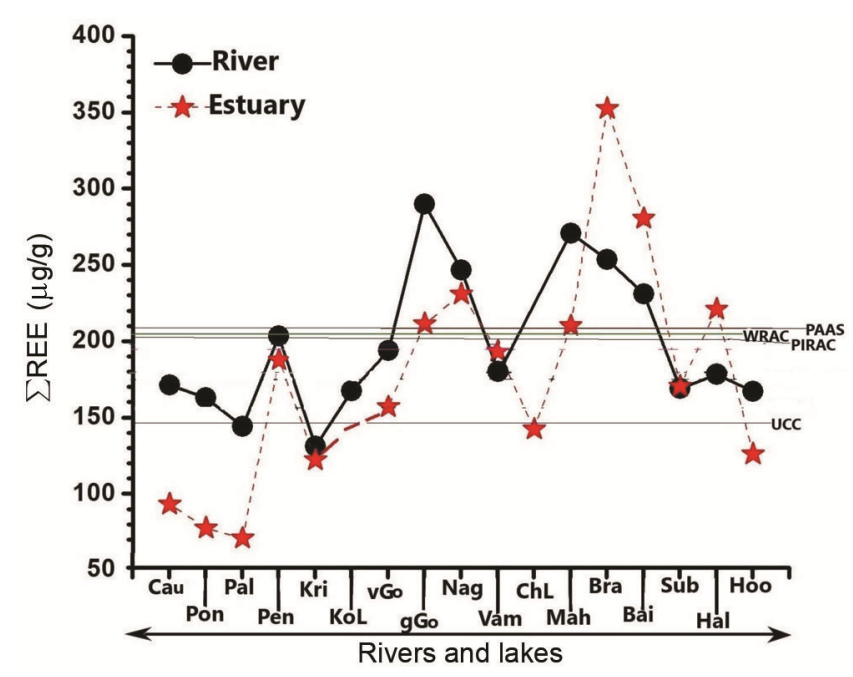

Figure 2. Total rare earth elements content ( $\mathrm{REE}$ ) of clay fraction of sediments in rivers, estuaries and lakes. Cav, Cauvery; Pon, Ponnaiyar; Pal, Palar; Pen, Pennar; Kri, Krishna; KoL, Kolleru Lake; vGo, Vasishta Godavari; gGo, Gautami Godavari; Nag, Nagavali; Vam, Vamsadhara; ChL, Chilika Lake; Mah, Mahanadi; Bra, Brahmani; Bai, Baitarani, Sub, Subarnarekha; Hal, Haldia; Hoo, Hoogly. The $\sum$ REE of Post-Archean average Australian Shale (PAAS), World River Average Clay (WRAC), Upper Continental Crust (UCC) and Peninsular India Rivers Average Clay (PIRAC) are also shown. 


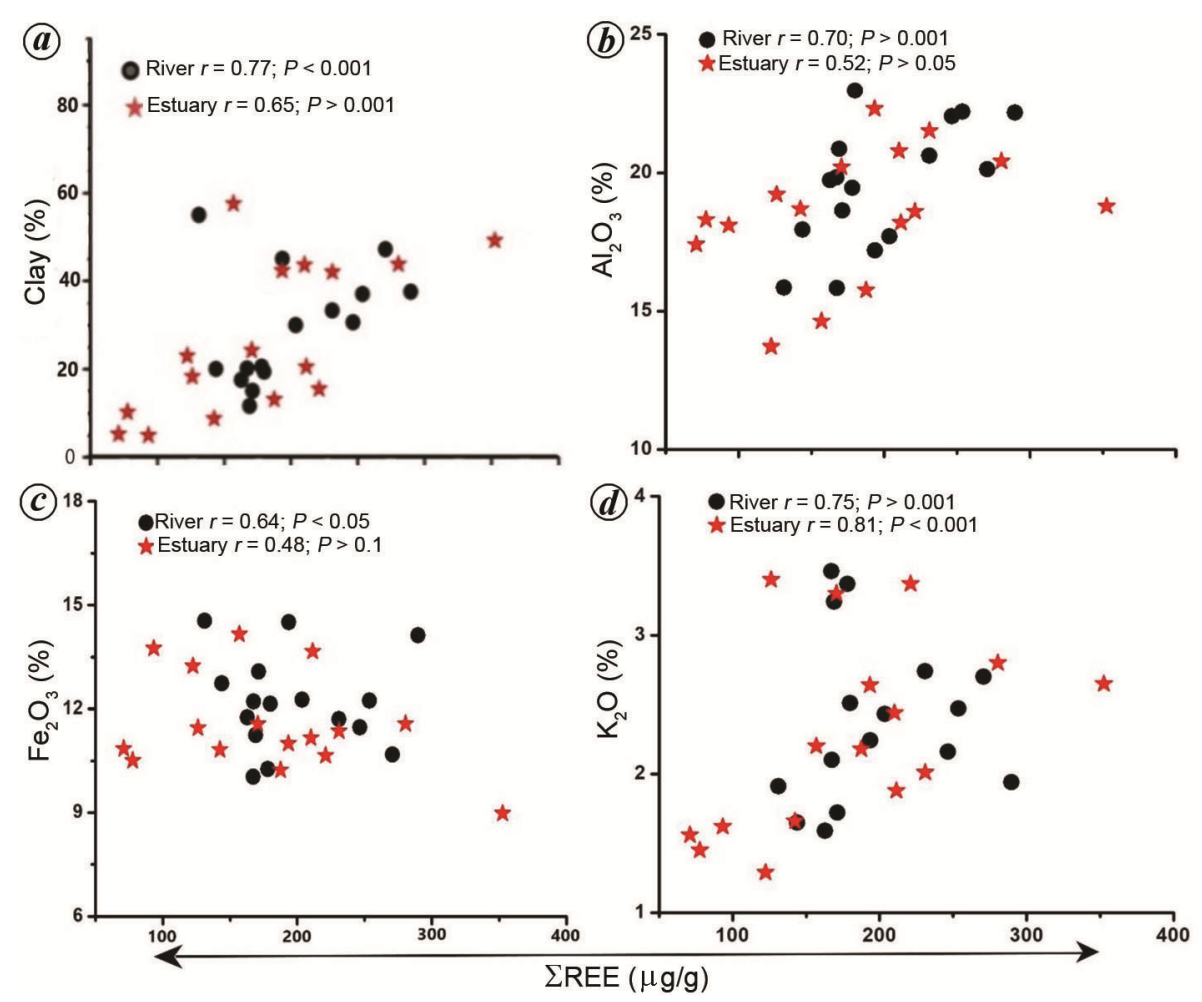

Figure 3. Plot of $\sum \mathrm{REE}$ with (a) clay, (b) $\mathrm{Al}_{2} \mathrm{O}_{3}$, (c) $\mathrm{Fe}_{2} \mathrm{O}_{3}$ and $(\boldsymbol{d}) \mathrm{K}_{2} \mathrm{O}$ content of clay in rivers and estuaries. $(P<0.001$ indicates statistically highly significant value, $P<0.05$ indicates statistically significant value and $P>0.001$ indicates significant value greater than 0.001$)$.

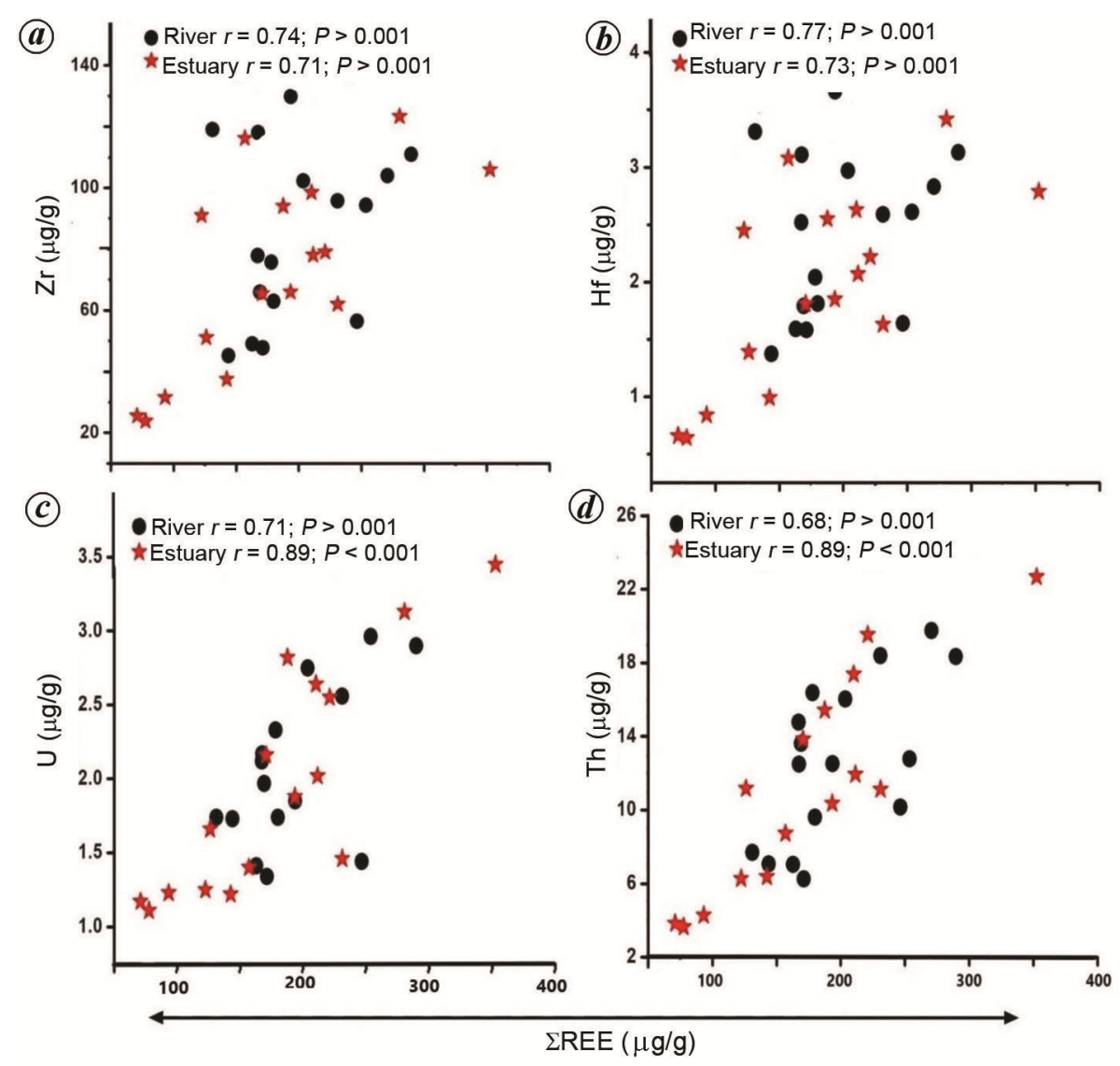

Figure 4. Plot of $\sum \mathrm{REE}$ with (a) $\mathrm{Zr},(\boldsymbol{b}) \mathrm{Hf},(\boldsymbol{c}) \mathrm{U}$ and $(\boldsymbol{d})$ Th of clays in rivers and estuaries. 

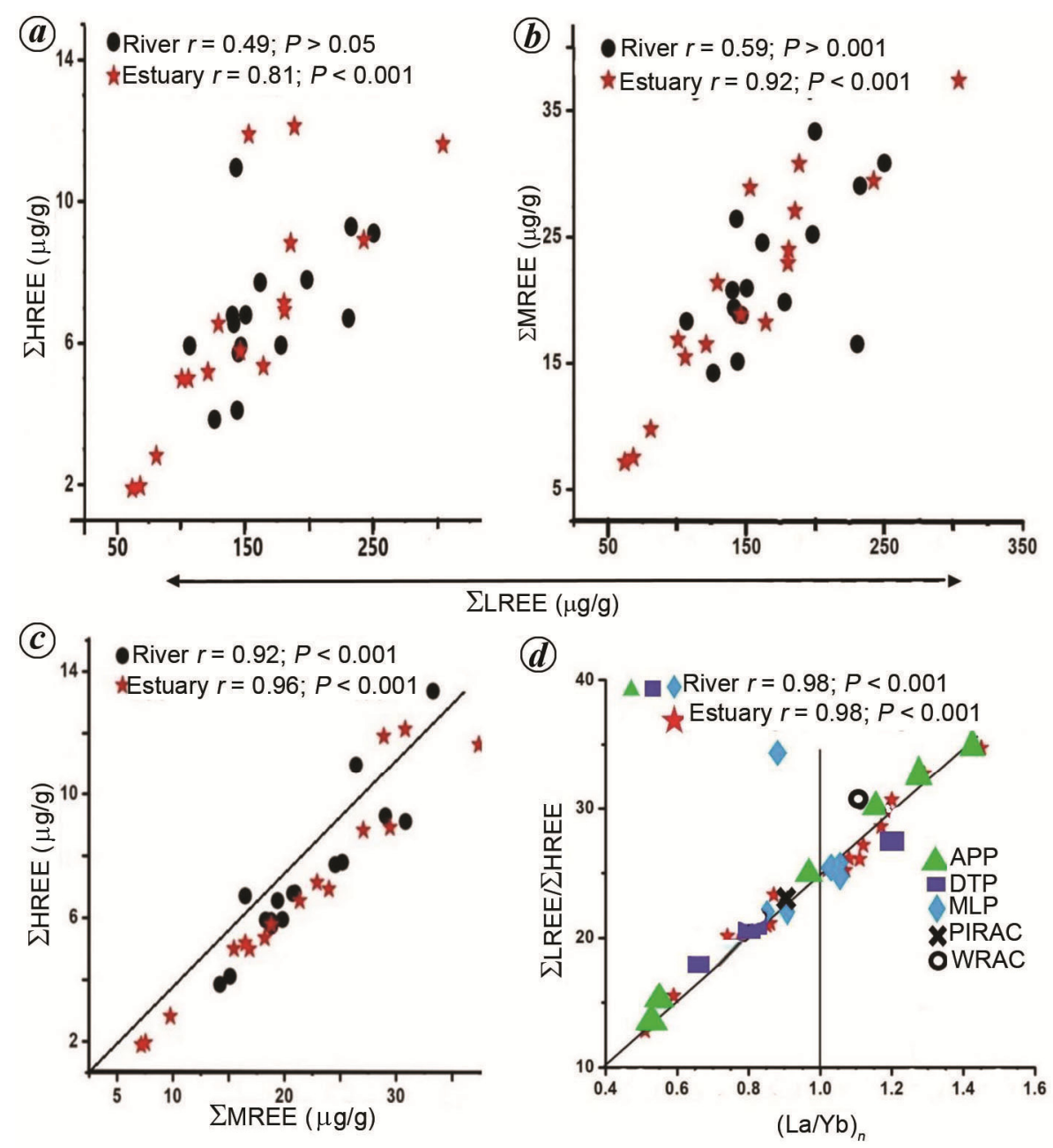

Figure 5. a , b, Plot of $\sum$ LREE with (a) $\sum$ HREE and (b) $\sum$ MREE. $\boldsymbol{c}, \boldsymbol{d}$, Plot of (c) $\sum$ MREE vs $\sum$ HREE and (d) $\sum \mathrm{LREE} / \sum \mathrm{HREE}$ vs $(\mathrm{La} / \mathrm{Yb})_{n}$ of clays in rivers and estuaries. The rivers draining the Archean and Pre-Cambrian Province (APP), Deccan Trap Province (DTP) and Mixed-Lithology Province (MLP) are demarcated with different coloured symbols. $(d)$ also shows the ratio of $\sum$ LREE/ $\sum$ HREE and $(\mathrm{La} / \mathrm{Yb})_{n}$ of WRAC ${ }^{18}$ and PIRAC $^{27}$.

Pre-cambrian crust (1.10), volcanic crust (1.16) and mixed lithology crust (1.10). The $\mathrm{Ce} / \mathrm{Ce}$ * values ranged from 1.0 to 1.22 in estuaries. The $\mathrm{Eu}$ anomaly $\left(\mathrm{Eu} / \mathrm{Eu}^{*}\right)$ values ranged from 1.17 to 1.52 and from 1.13 to 1.51 in the river and estuarine clays respectively (Figure $8 b$ ). The mean $\mathrm{Eu} / \mathrm{Eu}^{*}$ was highest for rivers draining dominantly the volcanic crust (1.43), followed by metamorphic crust (1.34) and mixed lithology crust (1.23).

\section{Discussion}

\section{Controls on $\Sigma R E E$ of clays}

Very high $\sum$ REE values in major and medium rivers (Figure 2) compared to that of PASS and WRAC imply that the abundance of REE is not dependent on the size of the drainage basin or the amount of detrital material supplied by rivers. It could be due to mineral composition in the clays (Table 1). Su et al. ${ }^{9}$ reported that mineral com- position of the sediments is the ultimate control for REE composition. The positive correlation of $\sum \mathrm{REE}$ with total clay content (Figure $3 a$ ), and $\mathrm{Al}_{2} \mathrm{O}_{3}$ and $\mathrm{K}_{2} \mathrm{O}$ (Figure $3 b$ ) in rivers suggest that the clay fraction is important as it contains abundant minerals, which are better host for $\mathrm{REE}^{43}$. Moreover, K-feldspar or K-rich clay also contributed to REE. Yang et al. ${ }^{24}$ reported high REE content corresponding to finer grain-size fractions of the sediments. The low $\sum$ REE associated with high clay content in Kolleru Lake (Table 3) indicates that the clay fraction alone is not responsible for variations in $\sum \mathrm{REE}$ content. Moderate correlation of $\Sigma \mathrm{REE}$ with $\mathrm{Fe}_{2} \mathrm{O}_{3}$ in river clay (Figure $3 c$ ) indicates association of REE with Fe-oxyhydroxides. Iron is known to exist as organically stabilized colloids in river water, and high REE are associated with high $\mathrm{Fe}$ in rivers ${ }^{20}$ and are also influenced by Fe-oxyhydroxides in the sediments ${ }^{23,46}$.

Strong correlation between $\Sigma$ REE and heavy metals (Figure $4 a-d$ ) suggests REE contribution from heavy

CURRENT SCIENCE, VOL. 120, NO. 3, 10 FEBRUARY 2021 

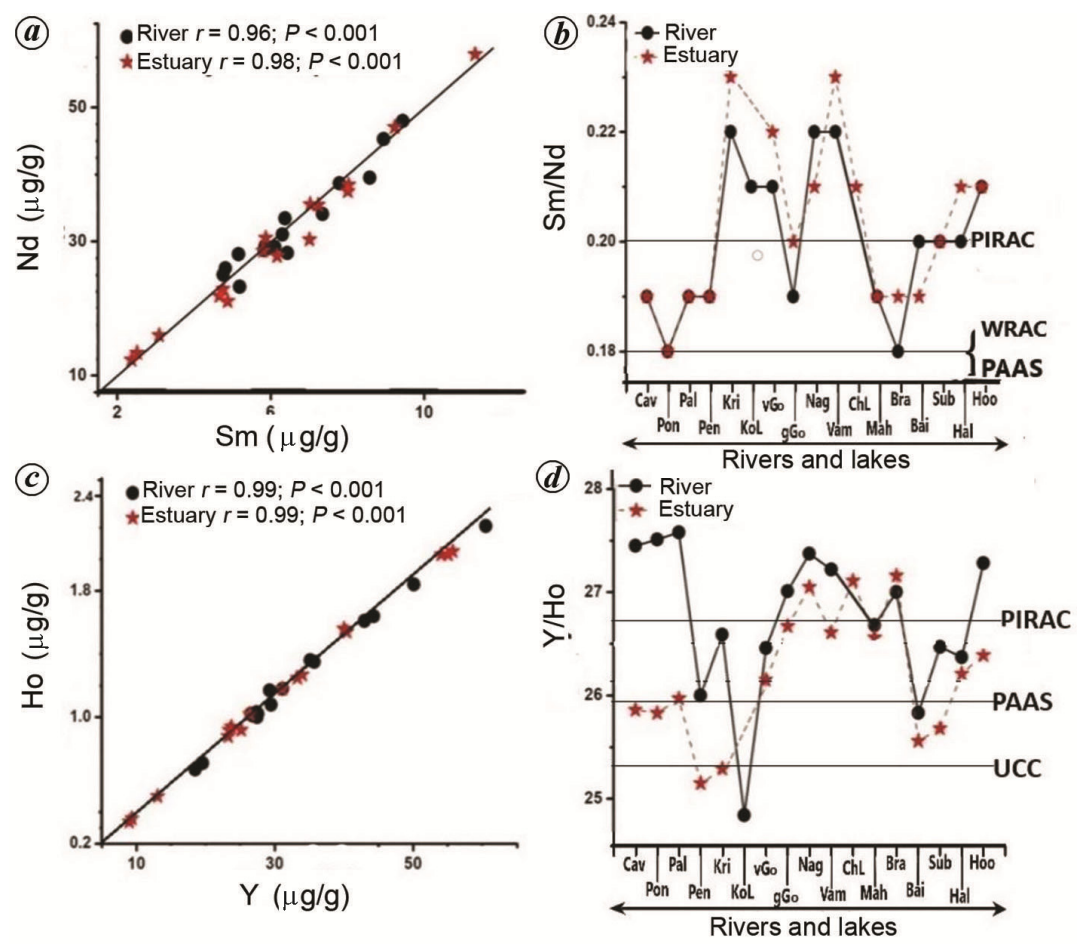

Figure 6. $\boldsymbol{a}, X-Y$ plot of $\mathrm{Sm}$ and $\mathrm{Nd}$ values of clay in rivers and estuaries. $\boldsymbol{b}$, Distribution of $\mathrm{Sm} / \mathrm{Nd} \mathrm{ratios}$ of clay in rivers and estuaries. The $\mathrm{Sm} / \mathrm{Nd}$ ratios of PAAS and WRAC are also shown. $c, X-Y$ plot of $Y$ and Ho values of clay in rivers and estuaries. $\boldsymbol{d}$, Distribution of $\mathrm{Y} / \mathrm{Ho}$ ratios of clay in rivers and estuaries.

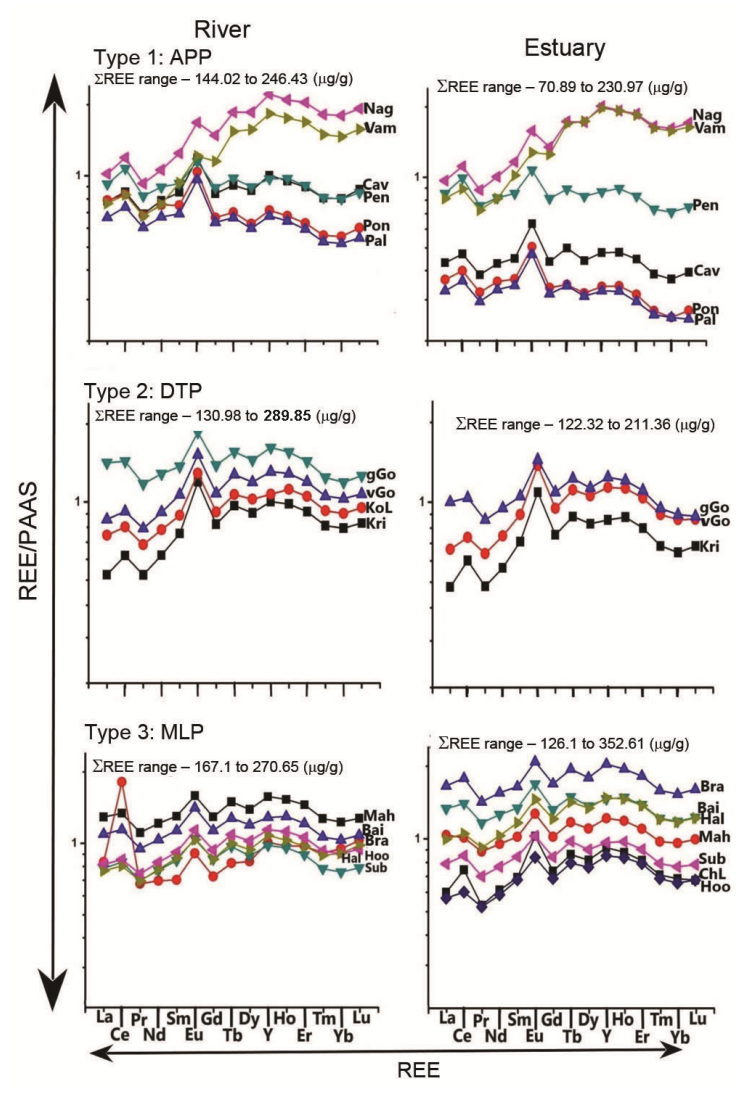

Figure 7. PAAS-normalized REE patterns of clay (type-1, type-2 and type 3 patterns) in rivers and estuaries. APP, Archand - Pre-Cambrian Province; DTP, Deccan Trap Province; MLP, Multi-lithology Province. minerals in the clay fraction. Heavy minerals have been reported both in sand and finer grain-size $(0.1-2.0 \mu \mathrm{m})$ fractions of sediments ${ }^{22,25,47}$. High concentration of heavy minerals has been reported in beach and nearshore sediments along the east coast of India; they are being mined at places for REE and radioactive metals and industrial metals ${ }^{48}$. The beaches of Tamil Nadu are enriched in garnet, ilmenite, zircon and magnetite, whereas the beaches of Andhra Pradesh consist of ilmenite, garnet, sillimanite, zircon and monazite ${ }^{49}$. Heavy minerals such as sillimanite, ilmenite, garnet, rutile, hornblende, zircon and monazite are important in both coastal dunes and beaches of Odisha. Charnockites and high-grade metamorphic rocks in the Eastern Ghats are responsible for the enriched concentration of heavy minerals. Therefore, heavy minerals in the finer-grain-size fractions of sediments may have contributed to REE enrichment. Moderate correlation between the carbonate content and $\sum$ REE in rivers suggests probable contribution from carbonate-associated minerals such as phosphorites.

Weathering results in solution of REE from the parent rock. The dissolved REE, REE associated with colloidal phases and particulate matter are transported to the estuaries and then extensively removed because of salt-induced coagulation. Therefore, high REE content is expected and reported in estuarine sediments ${ }^{5,50}$. However, in the present study $\sum$ REE in the estuaries was lower than in the rivers (Figure 2). Moderate to weak correlation of $\sum \mathrm{REE}$ with $\mathrm{Al}_{2} \mathrm{O}_{3}$ and $\mathrm{Fe}_{2} \mathrm{O}_{3}$ in the estuaries (Figure $3 b$ and $c$ ) 

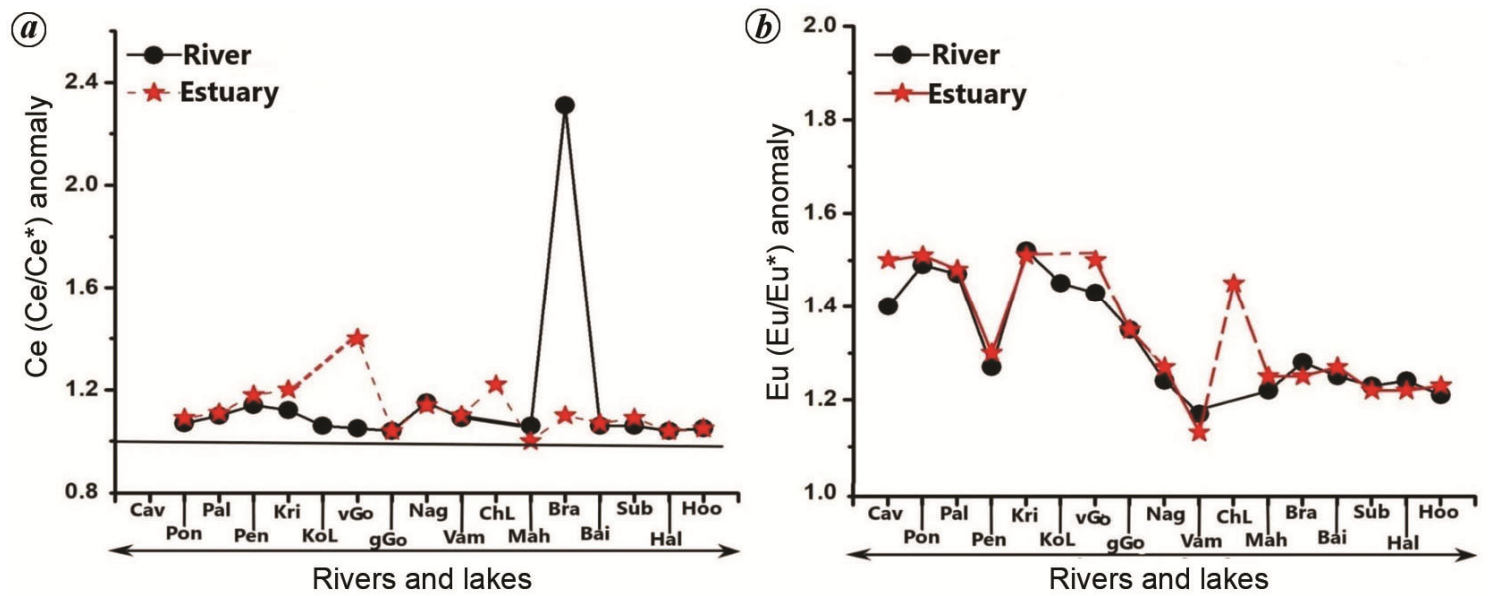

Figure 8. Distribution of $(\boldsymbol{a}) \mathrm{Ce}\left(\mathrm{Ce} / \mathrm{Ce}^{*}\right)$ and $(\boldsymbol{b}) \mathrm{Eu}\left(\mathrm{Eu} / \mathrm{Eu}^{*}\right)$ anomaly values in rivers and estuaries.

suggests that the REE removal processes are not active in low-salinity regions. Researchers have proposed that high $\mathrm{pH}$, low REE concentration and REE complexation with carbonate ions and natural organic ligands stabilize REE in solution, resulting in low REE removal to the sediments in low-salinity regions ${ }^{10,19}$. Negative correlation between $\Sigma$ REE and carbonate content in estuarine clay suggests that carbonate content dilutes the REE content.

The explanation for the relatively low $\sum$ REE in lowsalinity regions of estuaries is as follows: Almost all rivers of the east coast of India supply high sediment load to the estuaries either during the southwest monsoon (June-September) or the northeast monsoon (NovemberFebruary). Sediment supply through rivers is extremely low during other months. Therefore, it is possible that the REE-associated clays are quickly transported farther into the sea, because of strong river flow during the monsoons, resulting in less REE removal in low-salinity regions. Very high $\sum$ REE in the estuarine clay of the Brahmani and Baitarani (Table 4) suggests that more REE-associated minerals from deposits in their drainage basins are transported into the estuaries.

\section{PAAS-normalized REE patterns in rivers}

The MREE-enriched REE patterns (Figure 7) may have been caused by at least three factors. (i) REE of clay fraction has been analysed in the present study. Bayon et al. ${ }^{18}$ reported high MREE and HREE in clay fractions compared to the bulk sediment. (ii) Tropical conditions prevail in the drainage basins of all rivers and therefore chemical weathering is predominant. Nesbitt and Markovics $^{12}$ suggested that intense chemical weathering causes MREE-enrichment in river sediments. (iii) Rivers such as the Cauvery drain through phosphate-rich limestones. Weathering of phosphate minerals also causes MREE-enrichment ${ }^{20}$. Strong correlation between $\sum$ MREE and $\sum$ HREE (Figure $5 c$ ) indicates that MREE and HREE are from the same source. The REE patterns are categorized into three types (Figure 7 ).

Type-1 REE patterns: Although the geological formations and weathering conditions in the drainage basins are similar for the medium (Ponnaiyar and Palar) and major (Pennar and Cauvery) rivers, their REE patterns are different (Figure 7). These rivers drain the Archean and Pre-Cambrian formations comprising hornblende-biotite gneisses and granitoid gneisses in the upper reaches. In the lower reaches, the medium rivers drain Cretaceous sandstone and limestone with intercalated clay, whereas the major rivers drain basaltic intrusions intercalated with sandstone and limestone, laterites and alluvium (Table 1). The CIA values for the clay in medium (79-81) and major (77-81) rivers indicate that the rocks weather under moderate to high degree of chemical weathering. Under these conditions, HREE are preferentially released to the dissolved loads and the residual clay is enriched in LREE. The linear correlation of $\sum$ LREE/ $\sum$ HREE and $(\mathrm{La} / \mathrm{Yb})_{n}$ points to the LREE-enriched sediments (Figure $5 d)$. The high $(\mathrm{LREE} / \mathrm{HREE})_{n}$ and $(\mathrm{La} / \mathrm{Yb})_{n}$ ratios also indicate LREE enrichment (Table 3). LREE-enriched REE patterns were reported for sediments from the Archean metamorphic formations ${ }^{4}$. Bayon et al. ${ }^{18}$ suggested that the weathering of granitic/granodioritic soils results in significant LREE enrichment over other REE. The LREE- and MREE-enriched and HREE-depleted REE patterns in the Ponnaiyar and Palar rivers suggest that REE are controlled by the geology of their drainage basins.

The shale-like REE patterns in the Cauvery and Pennar (major) rivers indicate increased HREE concentration compared to the medium rivers (Figure 7). Relatively high smectite in these sediments indicates increasing proportions of swelling clay minerals that favour high cation exchange capacity (CEC) and high REE adsorption. 
The HREE released from the rocks in the upper reaches may have been adsorbed onto clays and Fe-oxyhydroxides during long-distance transport, and resulted in REE patterns close to the shale. Chang et al. ${ }^{16}$ attributed the fractionation between LREE and HREE to high adsorption affinity of REE to the secondary Fe, Mn and Al minerals in the soils. In other words, the shale-like REE patterns of the Cauvery and Pennar river clay are related to the mixing of upstream sediments with those in the lower reaches during long-distance transportation and sedimentation.

The Nagavali and Vamsadhara rivers drain the Eastern Ghats (mountain ranges) composed of Pre-Cambrian khondalites (Table 1). The manganese ores are intimately associated with khondalites ${ }^{34}$. High Mn content in the Nagavali river clay (Table 3) attests that the clay is weathered and eroded from these ores and transported short distances, as these Ghats are located close to the shore. Moriyama et al. ${ }^{35}$ reported HREE-enriched REE patterns with positive $\mathrm{Eu}$ anomaly in $\mathrm{Mn}$ ores. The LREE-depleted and HREE-enriched REE patterns in the Nagavali and Vamsadhara river clay could be due to the erosion from ore deposits and preferential weathering of felsic component of the metamorphic rocks, thus representing source-rock characteristics. Wide variations within the type-1 REE patterns imply that the abundance of REE depends on the chemical and mineral composition of rocks in the drainage basin and the extent of sediment mixing from different sources during transport. Su et al. ${ }^{9}$ suggested that the REE composition is controlled largely by mineral composition and clay minerals, $\mathrm{Mn}-\mathrm{Fe}$ hydroxides and secondary phosphate minerals.

Type-2 REE patterns: The LREE-depleted and MREEand HREE-enriched REE patterns are characteristic of clay from the Krishna and Godavari rivers and Kolleru Lake (Figure 7). The Godavari is the largest river in peninsular India. Vasishta Godavari is a tributary of the Godavari, separated from the main river (Gautami Godavari) in the lower reaches at $\sim 100 \mathrm{~km}$ from the Bay of Bengal. The basic volcanic rocks (Deccan Traps) cover $50 \%$ of the total drainage basin of the Godavari and, onethird of the drainage basin of the Krishna in the upper reaches (Table 1). Pre-Cambrian granitic and gneissic rocks and deltaic sediments occur in the middle and lower reaches of both rivers (Figure 1 and Table 1). Several studies have reported positive Eu anomaly and HREEenriched REE patterns as weathering products from volcanic rocks ${ }^{4,18}$. Ce anomaly is not the characteristic of basalts. The presence of $\mathrm{Ce}$ anomaly indeed shows mixing of volcanic sediments with gneissic rock-derived sediments in the lower reaches. Strong river flow and high sediment load from upstream during monsoon months may have dominated the clay in the lower reaches, favouring LREE-depleted and HREE-enriched patterns. In the Gautami Godavari, the LREE concentration is close to that of HREE (Figure 7). Gautami Godavari being a large/major river, the REE produced in the upper reaches may have been efficiently mixed with clay from the lower reaches during long-distance transport, resulting in shale-like pattern.

Type-3 REE patterns: The MREE-enriched patterns with near equal proportions of LREE and HREE are typical for the clay from the Mahanadi, Brahmani, Baitarini and Subarnarekha rivers (Figure 7). These rivers drain through igneous and metamorphic rocks, abundant mineral (ilmenite, rutile, zirconium and rare earth minerals) and ore deposits of both $(\mathrm{Fe}-\mathrm{Mn})$ oxides and $(\mathrm{Cu}-\mathrm{Pb})$ sulphides in the upper reaches, and lateritic, yellow and red soils and deltaic sediments in the middle and lower reaches (Table 1). The Fe-Mn oxide ores exhibit LREEdepleted and MREE- and HREE-enriched REE patterns with positive $\mathrm{Ce}$ and $\mathrm{Eu}$ anomalies ${ }^{35,51,52}$. The LREEenriched REE patterns are characteristic of $\mathrm{Cu}$ and $\mathrm{Zn}$ sulphide deposits, and $\mathrm{Pb}$ sulphides exhibit HREEenriched patterns with positive $\mathrm{Eu}$ anomaly ${ }^{53}$. Positive correlation of $\sum$ REE with heavy metals (Figure 4) suggests that the REE composition is influenced by heavy minerals, which were reported even in the $0.1-2.0 \mu \mathrm{m}$ size range of sediments ${ }^{19,22}$. Minerals such as garnet, zircon and xenotime produce HREE-enriched patterns, while monazite and allanite produce LREE-enriched REE patterns ${ }^{4,23,24}$. Strong correlation of $\sum$ REE with $\mathrm{K}_{2} \mathrm{O}$ content (Figure $3 d$ ) suggests REE contribution from Kfeldspars and micas, common in granites and high-grade metamorphic rocks. Alteration of K-feldspar produces LREE-enriched patterns with positive $\mathrm{Eu}$ anomaly ${ }^{43}$. High $\sum$ REE and shale-like REE pattern of these four rivers thus demonstrates efficient mixing of clay from different lithologies.

The Haldia and Hoogly river clay exhibits slightly enriched HREE (av $\left.(\mathrm{Lu} / \mathrm{La})_{n}=1.22\right)$ over LREE (av $(\mathrm{La} / \mathrm{Yb})_{n}=0.87$; Figure 7$)$. These are medium rivers and tributaries of the Ganges, which drains Pre-Cambrian metamorphic rocks from the Himalaya and sedimentary formations in the lower reaches. The low CIA values for the clay in these rivers (75-77) attest more of physical weathering products than chemical weathering. The clays derived from felsic component of metamorphic rocks and reworked sedimentary formations probably yielded slight HREE-enrichment over LREE.

\section{PAAS-normalized REE patterns in estuarine sediments}

The $\sum$ REE of estuarine clay are 3-50\% lower than in their rivers (Figure 2). However, the PAAS-normalized REE patterns of estuarine clay are nearly similar to those of rivers (Figure 7). Indeed, one would expect significant fractionation of REE in the low-salinity regions of 
estuaries because of the salt-induced coagulation of particulates and changing proportion of colloidal and dissolved REE pools. Elderfield et al. $^{5}$ reported increased $\sum$ REE content from $\sim 30 \%$ to near quantitative in the lowsalinity regions. The low $\sum$ REE content in the estuarine clay could be due to other factors (high $\mathrm{pH}$, low REE concentration and solution complexation) ${ }^{19,20}$ or, as mentioned earlier, strong river flow during monsoon months most probably inhibited estuarine processes and quickly transported river sediments to the continental shelf. In other words, hydrodynamic conditions control REE abundance and fractionation in the estuaries.

\section{Ce and Eu anomalies}

$\mathrm{Ce}$ in river sediments tends to be unfractionated with respect to other LREE. However, $\mathrm{Ce}^{3+}$ oxidizes to less soluble $\mathrm{Ce}^{4+}$ in estuarine and marine water, and is rapidly removed to the sediments by particle scavenging. Therefore, one would expect pronounced negative Ce anomaly in seawater and positive $\mathrm{Ce}$ anomaly in the estuarine sediments ${ }^{6}$. Nearly identical Ce anomaly values in the clay of each river and estuary (Figure $8 a$ ), imply that $\mathrm{Ce}$ is unfractionated in the low-salinity regions of estuaries. The strong and efficient river flow probably inhibited estuarine processes and therefore there was no significant change in $\mathrm{Ce} / \mathrm{Ce}^{*}$ in rivers and low-salinity regions of estuaries. Since $\mathrm{Ce} / \mathrm{Ce}$ * is weakly correlated with $\mathrm{Fe}_{2} \mathrm{O}_{3}$ or $\mathrm{MnO}$ in both rivers and estuaries, $\mathrm{Ce}$ is not associated with $\mathrm{Fe}-\mathrm{Mn}$ oxyhydroxide phases. High $\mathrm{Ce}$ anomaly in the Brahmani River may be from the hinterland heavy minerals enriched in the clay fractions.

Positive Eu anomaly is characteristic of charnokites of southern India ${ }^{54}$, banded-iron formations, Pre-Cambrian gniesses, Fe-Mn-bearing arenites, hydrothermal and volcanic sediments and anthropogenic organic pollutants ${ }^{55,56}$. High Eu anomaly values in rivers draining volcanic rocks, followed by metamorphic rocks and mixed lithology formations are in agreement with the lithological formations in their drainage basins. No significant change in the absolute Eu anomaly in the river and estuarine clay indicates that $\mathrm{Eu}$ is not influenced by estuarine processes.

\section{Controls on $\mathrm{Sm} / \mathrm{Nd}$ ratio of sediments}

Strong correlation between $\mathrm{Sm}$ and $\mathrm{Nd}$ both in river and estuarine clay (Figure 6a) suggests their similar geochemical behaviour during weathering, and the $\mathrm{Sm} / \mathrm{Nd}$ ratio is unaffected. Similar $\mathrm{Sm} / \mathrm{Nd}$ ratios $(\sim 0.201)$ of clay in rivers draining the Archean and Pre-Cambrian crust and mixed lithology (Figure $6 b$ ) and a value close to that of the Ganges River sediments (0.205) indicate mixing of REE from different sources.

The relatively high $\mathrm{Sm} / \mathrm{Nd}$ ratio of clay from volcanic crust $(0.211$; Figure $6 b)$ is in agreement with the fact that this ratio increases linearly with decreasing age $e^{57}$. Both $\mathrm{Sm}$ and $\mathrm{Nd}$ are REE. The REE-bearing minerals respond differently during differential weathering ${ }^{50,58}$. For example, $\mathrm{Nd}$ from feldspar is easily weathered during intense chemical weathering. The weathered products such as clay exhibit low $\mathrm{Sm} / \mathrm{Nd}$ ratio and residual rock/coarser sediments exhibit high $\mathrm{Sm} / \mathrm{Nd}$ ratio. Thus, the sediments derived from basalts or those with felsic composition show high $\mathrm{Sm} / \mathrm{Nd}$ ratio. Therefore, the high $\mathrm{Sm} / \mathrm{Nd}$ ratio represents mineral composition of the sediments. High $\mathrm{Sm} / \mathrm{Nd}$ ratio of clay from the Nagavali and Vamsadhara (Figure $6 b$ ) may be because of ore minerals in the clay fraction; their original ratio is preserved because the rivers are medium in size and drain mono-lithology.

Since the REE chemistry of $<4 \mu \mathrm{m}$ fraction of sediments alone was studied, the influence of grain size on $\mathrm{Sm} / \mathrm{Nd}$ ratio cannot be ascertained. The $\mathrm{Sm} / \mathrm{Nd}$ ratio is 0.198 for major river sediments with high clay content (37-47\%) and for medium river sediments with low clay content $(<30 \%)$. Similarly, high $\mathrm{Sm} / \mathrm{Nd}$ ratio $(0.201-$ 0.223 ) is associated with the Krishna (a major river) with high clay content $(45-55 \%)$ and medium rivers with low clay content $(<30 \%)$. This implies that the $\mathrm{Sm} / \mathrm{Nd}$ ratio is determined by mineral composition of clay rather than clay content of the sediments.

\section{Y/Ho ratio}

Strong positive correlation between $\mathrm{Y}$ and Ho (Figure $6 c$ ) suggests their similar geochemical behaviour. The Y/Ho ratio of clay from the Archean and Pre-Cambrian crust (av 27.2) is close to that of PAAS: (27.4), suggesting that high ratios reflect metamorphic crust. Feng ${ }^{50}$ reported high $\mathrm{Y}$ values associated with metamorphic rocks, laterites, Fe-Mn deposits and heavy minerals. Lowest Y/Ho ratio (av 26.2) for clay from volcanic rocks (Figure $6 d$ ) supports the findings of Bau and $\mathrm{Zhao}^{58}$ that this ratio is lower in basaltic rocks (21.9-26.5) than in granitic rocks (25-47). This ratio is $\sim 26.0$ in the Pennar and Baitarani river clay (Figure $6 d$ ), and is associated with high $\mathrm{Fe}$ and $\mathrm{Mn}$. It suggests greater adsorption of Ho onto organic-rich clayey particulates and/or $\mathrm{Fe}$ and $\mathrm{Mn}$ particulates leading to low $\mathrm{Y} / \mathrm{Ho} \operatorname{ratios}^{50,59}$. Since Fe-oxyhydroxides have greater affinity for Ho relative to $\mathrm{Y}$, it is likely that Ho is adsorbed on these particulates resulting in low $\mathrm{Y} / \mathrm{Ho}$ ratio.

Fractionation of $\mathrm{Y} / \mathrm{Ho}$ ratio usually occurs during weathering and transportation from river to estuary. Strong fractionation of $\mathrm{Y} / \mathrm{Ho}$ ratio in the estuaries of the Cauvery, Ponnaiyar, Palar, Pennar and Krishna (Figure $6 d$ ) may be because Ho displays different complexation properties in marine systems and is scavenged on particulate matter two times faster than Y (ref. 59). Strong river flow in other estuaries (Figure $6 d$ ) may have inhibited estuarine processes and therefore little fractionation of $\mathrm{Y} / \mathrm{Ho}$ ratio.

CURRENT SCIENCE, VOL. 120, NO. 3, 10 FEBRUARY 2021 


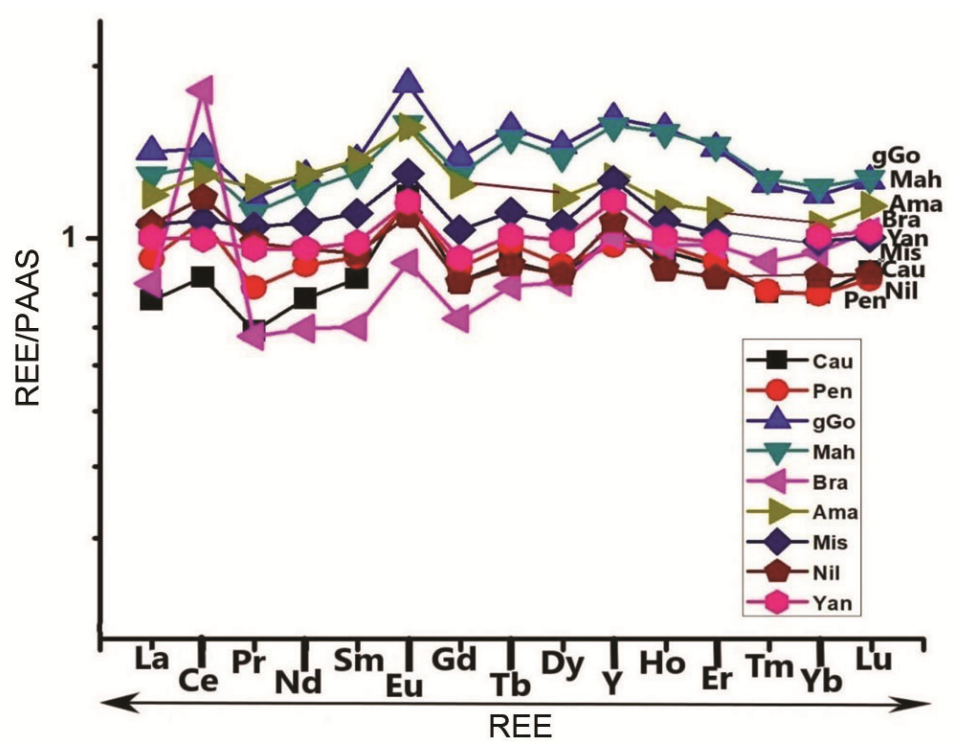

Figure 9. PAAS-normalized REE patterns of major rivers of peninsular India and major tropical rivers of the world. (Ama, Amazon; Nil, Nile; Mis, Mississippi and Yan, Yangtez Rivers); REE values for the Amazon, Nile, Mississippi, Yantze rivers are from Bayon et al. ${ }^{18}$.

\section{REE patterns of clays for major rivers in India and the world}

Except the Krishna, other major rivers exhibit slight MREE enrichment with near equal proportions of LREE and HREE, similar to that of shale (Figure 9). The uniform shale-like REE patterns suggest effective mixing of clay from different sources during erosion, transportation and deposition. On the other hand, sediments in the major tropical rivers of the world exhibit uniform LREEenriched patterns (Figure 9) attributed to efficient mixing of sediments during erosion, transportation and deposition $^{4,24}$. In other words, clay in the Indian major rivers shows slightly enriched MREE and HREE compared to that of major rivers in the world.

\section{Conclusion}

The distribution and fractionation of REE in the clay fraction of sediments in 15 rivers, their estuaries and two lakes in the east coast of India indicate the following: (i) $\sum$ REE of the river clay is controlled by the mineral composition of sediments. (ii) The PAAS-normalized REE patterns in river clay are of three types. They are controlled by the dominant geological formations in their drainage basins and extent of sediment mixing during transport and sedimentation. (iii) Low $\sum$ REE in estuarine clay compared to their rivers, and similar REE patterns in both rivers and estuaries suggest that REE removal to the sediments is controlled by hydrodynamic conditions in low-salinity regions of estuaries. (iv) $\mathrm{The} \mathrm{Sm} / \mathrm{Nd}$ ratios of clay are in agreement with the age of major geological formations in the drainage basins and mineral composition of sediments. (v) The $\mathrm{Y} / \mathrm{Ho}$ ratios in rivers simply reflect source-rock signatures, while in estuaries the lower ratios reflect complexation processes of Ho onto $\mathrm{Fe}-\mathrm{Mn}$ oxyhydroxides and organic particulates.

1. McLennan, S. M., Rare earth elements in sedimentary rocks: influence of provenance and sedimentary processes. In Reviews in Mineralogy. Geochemistry and Mineralogy of Rare Earth Elements (eds Lippin, B. R. and McKay, G. A.), De Gruyter, 1989, vol. 21, pp. 169-200; https://doi.org/10.1515/9781501509032.

2. Rollinson, H., Using trace elements data. In Using Geochemical Data: Evaluation, Presentation, Interpretation (ed. Rollinson, H.,), Prentice Hall, Pearson, 1993, pp. 133-134.

3. Nance, W. B. and Taylor, S. R., Rare earth element patterns and crustal evolution - I. Australian post-Archean sedimentary rocks. Geochim. Cosmochim. Acta, 1976, 61, 1539-1551.

4. Goldstein, S. J. and Jacobsen, S. B., Rare earth elements in river waters. Earth Planet. Sci. Lett., 1988, 89, 35-47.

5. Elderfield, H., Upstillgoddard, R. and Sholkovitz, E. R., The rare earth elements in rivers, estuaries, and coastal seas and their significance to the composition of ocean waters. Geochim. Cosmochim. Acta, 1990, 54, 971-991.

6. Sholkovitz, E. R. and Szymezak, R., The estuarine chemistry of rare earth elements: comparison of the Amazon, Fly, Sepik and Gulf of Papua systems. Earth Planet. Sci. Lett., 2000, 178, 299 309.

7. Shiller, A. M., Seasonality of dissolved rare earth elements in the lower Mississippi River. Geochem. Geophys. Geosyst., 2002, 3, $1068-1078$.

8. Martins, M. V. A. et al., Rare earth elements as fingerprints of differentiated sediment sources in the Ria de Aveiro (Portugal). J. Sediment. Environ., 2016, 1, 17-42.

9. Su, N., Yang, S., Guo, Y., Yue, W., Wang, K., Yin, P. and Huang, K., Revisit of REE fractionation during chemical weathering and river sediment transport. Geochem. Geophys. Geosyst., 2017, 18, 935-955. 
10. Adebayo, S. B., Cui, M., Hong, T., White, C. D., Martin, E. E. and Johannesson, K. H., Rare earth element geochemistry and Nd isotopes in the Mississipi River and Gulf of Mexico Mixing zone. Front. Mar. Sci., 2018, 5, 166.

11. Braun, J. J., Pagel, M., Herbillon, A. and Rosin, C., Mobilization and redistribution of REEs and thorium in a syenitic lateritic profile: a mass balance study. Geochim. Cosmochim. Acta, 1993, 57, 4419-4434.

12. Nesbitt, H. W. and Markovics, G., Weathering of granodiorite crust, long-term storage of elements in weathering profiles, and petrogenesis of siliciclastic sediments. Geochim. Cosmochim. Acta $1997,61,1653-1670$.

13. Négrel, P., Water-granite interaction: clues from strontium, neodymium and rare earth elements in soil and waters. Appl. Geochem., 2006, 21, 1432-1454.

14. Shynu, R, Rao V. P., Kessarkar, P. M. and Rao, T. G., Rare earth elements in suspended and bottom sediments of the Mandovi estuary, central west coast of India: influence of mining. Estuarine Coast. Shelf Sci., 2011, 94, 355-368.

15. Ohlander, B., Land, M., Ingri, J. and Widerlund, A., Mobility and transport of $\mathrm{Nd}$ isotopes in the vadose zone during weathering of granitic till in a Boreal forest. Aquat. Geochem., 2014, 20, 1-17.

16. Chang, C., Li, F., Liu, C., Guo, J., Tong, H. and Chen, M., Fractionation characteristics of Rare earth elements linked with secondary Fe, Mn and Al minerals in soils. Geochem. Cosmochim. Acta, 2016, 35, 329-339.

17. Freslon, N. et al., Rare earth elements and neodymium isotopes in sedimentary organic matter. Geochim. Cosmochim. Acta, 2014, 140, 177-198.

18. Bayon, G. et al., Rare earth elements and neodymium isotopes in world river sediments revisited. Geochim. Cosmochim. Acta, 2015, 170, 17-38.

19. Marsac, R., Banik, N. L., Lutzenkirchen, J., Catrovillet, C., Masquardt, C. M. and Johannesson, K. H., Modeling metal ion-humic substances complexation in highly saline conditions. Appl. Geochem., 2017, 79, 52-64.

20. Merchel, G., Bau, M. and Dantas, E. L., Contrasting impact of organic and inorganic nanoparticles and colloids on the behaviour of particle-reactive elements in tropical estuaries: an experimental study. Geochem. Cosmochem. Acta, 2017, 197, 1-13.

21. Sharma, A. and Rajamani, V., Weathering of gneissic rocks in the upper reaches of Cauvery River, South India: implications to neotectonics of the region. Chem. Geol., 2000, 166, 203-223.

22. Marchandise, S., Robin, E., Ayrault, S. and Roy-Barman, M. U-Th-REE-Hf bearing phases in Mediterranean Sea sediments: implications for isotope systematics in the ocean. Geochim. Cosmochim. Acta, 2014, 131, 47-61.

23. Jung, H. S., Lim, D., Choi, J. Y., Yoo, H. S., Rho, K. C. and Lee, H. B., REE compositions of core sediments from the shelf of the South Sea, Korea; their controls and origins. Cont. Shelf Res., 2012, 48, 75-86.

24. Yang, S. Y., Jung, H. S., Choi, M. S. and Li, C. X., The rare earth element compositions of the Changjiang (Yangtze) and Huanghe (Yellow) river sediments. Earth Planet. Sci. Lett., 2002, 201, $407-$ 419.

25. Cavalcante, F., Belviso, C., Piccarreta, G. and Fiore, S., Grain-size control on the rare earth elements distribution in the late diagenesis of Cretaceous shales from the southern Apennines (Italy). J. Chem., 2014; Article ID: 841747.

26. Sensarma, S., Rajamani, V. and Tripathi, J. K., Petrography and geochemical characteristics of the sediments of the small River Hemavati, southern India: implications for provenance and weathering processes. Sediment. Geol., 2008, 205, 111-125.

27. Sai Babu, S., Ramana, R. V., Purnachandra Rao, V., Ram Mohan, M., Keshav Krishna, A., Sawant, S. and Satyasree, N., Composition of the peninsular India rivers average clay (PIRAC): a reference sediment composition for the upper crust from peninsular
India. J. Earth Syst. Sci., 2020, 129; https://doi.org/10.1007/ s12040-019-1301-8.

28. GSI, Geological Map of India; Geological Survey of India, Bangalore, 1998; 7 th edn.

29. Rao, K. L., India's Water Wealth, Orient Longman Ltd, New Delhi, 1975, p. 255.

30. Krishnan, M. S., Geology of India and Burma, Higginbotham, Madras, 1982, p. 536.

31. Balakrishnan, S. and Rajamani, V., Geochemistry and petrogenesis of granite gneisses around the Kolar Schist Belt, South India: petrogenetic constraints for the evolution of the crust in the Kolar area. J. Geol., 1987, 95, 219-240.

32. Das, A., Krishnaswami, S., Sarin, M. M. and Pande, K., Chemical weathering in the Krishna Basin and Western Ghats of the Deccan Traps, India: rate of basalt weathering and their controls. Geochim. Cosmochim. Acta, 2005, 69, 2067-2084.

33. Jha, P. K., Tiwari, J., Singh, U. K., Kumar, M. and Subramanian, V., Chemical weathering and associated $\mathrm{CO}_{2}$ consumption in the Godavari river basin, India. Chem. Geol., 2009, 264, 364-374.

34. Dash, B., Sahu, K. N. and Bowes, D. R., Geochemistry and original nature of Precambrian khondalites in the Eastern Ghats, Orissa, India. Trans. R. Soc. Edinburgh, 1987, 78, 115-127.

35. Moriyama, T., Panigrahi, M. K., Pandit, D. and Watanabe, Y., Rare earth element enrichment in Late Archean manganese deposits from the Iron Ore Group, East India. Resour. Geol., 2008, 58, $402-413$.

36. Bhattacharya, S., Chaudhary, A. K. and Basei, M., Original nature and source of khondalites in the Eastern Ghats Province, India. In Palaeoproterozoic of India (eds Mazumder, R. and Saha, D.), Geological Society of London Special Publication, 2012, pp. 147159.

37. Giri, S., Singh, A. K. and Tewary, B. K., Source and distribution of metals in bed sediments of Subarnarekha River, India. Environ. Earth Sci., 2013, 70, 3381-3392.

38. Biswas, A. N., Geohydro-morphometry of Hooghly estuary. J. Inst. Eng. (India), 1985, 66, 61-73.

39. Folk, R. L., Petrology of Sedimentary Rocks, Hemphils Pub. Co., Austin, Texas, USA, 1968, p. 170.

40. Satyanarayanan, M., Balaram, V., Sawant, S. S., Subramanyam, K. S. V., Vamsi Krishna, G., Dasaram, B. and Manikyamba, C., Rapid determination of REEs, PGEs, and other trace elements in geological and environmental materials by high resolution inductively coupled plasma mass spectrometry. Atom. Spectrosc., 2018, 39, $1-15$.

41. Govindaraju, K., Compilation of working values and descriptions for 383 geostandards. Geostand. Newsl., 1994, 18, 1-158.

42. Nesbitt, H. W. and Young, G. M., Early proterozoic climates and plate motions inferred from major element chemistry of lutites. Nature, 1982, 299, 715-717.

43. Taylor, S. R. and McLennan, S. M., The Continental Crust: Its Composition and Evolution. An Examination of the Geochemical Record Preserved in Sedimentary Rocks, Blackwell Scientific Publications, Oxford, UK, 1985, p. 312.

44. Pourmand, A., Dauphas, N. and Ireland, T. J., A novel extraction chromatography and $\mathrm{MC}-\mathrm{ICP}-\mathrm{MS}$ technique for rapid analysis of REE, Sc and Y: revising CI-chondrite and post-Archean Australian Shale (PAAS) abundances. Chem. Geol., 2012, 291, 38-54.

45. Rudnic, R. L. and Gao, S., The composition of the continental crust. In Treatise on Geochemistry (eds Rudnick, R. L., Holland, H. D. and Turekian, K. T.), Elsevier Pergamon, Oxford, UK, 2003, vol. 3, pp. 1-64.

46. Vazquez-Ortega, A. et al., Rare earth elements as reactive tracers of biogeochemical weathering in forested rhyolitic terrain. Chem. Geol., 2015, 391, 19-32.

47. Rickli, J., Frank, M., Baker, A. R., Aciego, S., de Souza, G., Georg, R. B. and Halliday, A. N., Hafnium and neodymium isotopes in surface waters of the eastern Atlantic Ocean: implications 
for sources and inputs of trace metals to the ocean. Geochim. Cosmochim. Acta, 2010, 74, 540-557.

48. Sengupta, D. and Van Gosen, B. S., Placer-type rare earth element deposits. Econ. Geol., 2016, 18, 81-100.

49. Rao, C. N., Anu Radha, B., Reddy, K. S. N., Dhanamjayarao, E. N. and Dayal, A. M., Heavy mineral distribution studies in different micro-environments of Bhimunipatnam coast, Andhra Pradesh, India. Int. J. Sci. Res. Publ., 2012, 2(5), 2250-3153.

50. Feng, J., Behaviour of rare earth elements and yttrium in ferromanganese concretions, gibbsite spots, and the surrounding terra rossa over dolomite during chemical weathering. Chem. Geol., 2010, 271, 112-132.

51. Shynu, R., Rao, V. P., Parthiban, G., Balakrishnan, S., Narvekar, T. and Kessarkar, P. M., REE in suspended particulate matter and sediment of the Zuari estuary and adjacent shelf, western India: influence of mining and estuarine turbidity. Mar. Geol., 2013, 346, 326-342.

52. Prajith, A., Rao, V. P. and Chakraborty, P., Distribution, provenance and early diagenesis of major and trace metals in sediment cores from the Mandovi estuary, western India. Estuarine Coast. Shelf Sci., 2016, 170, 173-185.

53. Graf Jr, J. L., Rare earth elements as hydrothermal tracers during the formation of massive sulphide deposits in volcanic rocks. Econ. Geol., 1977, 72, 527-548.

54. Allen, P., Condie, K. C. and Narayana, B. L., The geochemistry of prograde and retrograde charnockite-gneiss reactions in southern India. Geochim. Cosmochim. Acta, 1985, 49, 323-336.

55. Srinivasan, R., Naqvi, S. M., Uday, Raj, B., Subbarao, D. V., Balaram, V. and Rao, T. G., Geochemistry of the Archaean greywackes from the north western part of Chitradurga schist belt,
Dharwar Craton, South India - evidence for granetoid upper crust in the Archaean. J. Geol. Soc. India, 1989, 34, 505-516.

56. Tang, J. and Johannesson, K. H., Speciation of rare earth elements in natural terrestrial waters: assessing the role of dissolved organic matter from the modelling approach. Geochim. Cosmochim. Acta, 2003, 67, 2321-2339.

57. Condie, K. C., Another look at rare earth elements in shales. Geochim. Cosmochim. Acta, 1991, 55, 2527-2531.

58. Bau, M. and Zhao, Z., Geochemistry of mineralization with exchangeable REY in the weathering crust of granitic rocks in South China. Ore Geol. Rev., 2008, 35, 519-535.

59. Bau, M., Dulski, P. and Moller, P., Yttrium and holmium in South Pacific seawater: vertical distribution and possible fractionation mechanisms. Chem. Erde, 1995, 55, 1-15.

ACKNOWLEDGEMENTS. We thank the Vice-Chancellor, Vignan's University (VU), Vadlamudi and Director, CSIR-NGRI, Hyderabad for their encouragement. This work was carried out under CSIR Emeritus Scientist-scheme and Fellowship to V.P.R. S.S.B. was supported through funds from JC Bose National Fellowship to V.P.R. and from VU. We thank Ch. Venkatesh, K. Hemanth, A. Sagar and G. Subhash (Department of Civil Engineering, VU) for help in the collection of samples during field trips.

Received 3 March 2020; revised accepted 15 October 2020

doi: $10.18520 / \mathrm{cs} / \mathrm{v} 120 / \mathrm{i} 3 / 519-537$ 